RESEARCH ARTICLE / ARAŞTIRMA MAKALESİ

\title{
Türkiye'de Bir Kamu Politikası Olarak İklim Değişikliği: Tarihsel Gelişim, Uluslararası Müzakereler, Yapısal ve İdari Sorunlar Çerçevesinde Bir Değerlendirme
}

\author{
Climate Change Policy in Turkey: A Perspective of Analysis \\ through Historical Development, International Negotiations and \\ Administrative Obstacles
}

Fethi Ufuk ÖZIŞIK ${ }^{*}$ iD

Öz

Türkiye’de iklim değişikliği sorununa ilişkin merkezi yönetimin bir takım politikaları, kurumsal yapılanmayı ve çeşitli araçları gündemine alması Kyoto Protokolü sürecine denk düşmektedir. Bu çalışmada özellikle Kyoto Protokolü’ne taraf olunmasını takiben devletin iklim değişikliği ile ilgili bütüncül ve etkin bir kamu politikasını hayata geçirip geçir(e)mediği irdelenecektir. Konu ile ilgili değerlendirmelerde Türkiye’nin Kyoto Protokolü’ne kadar iklim değişikliğini bir dış politika konusu olarak ele aldığı ve algıladığı söylenmektedir. Ne var ki, o tarihten bugüne uzanan gelişmelere bakıldığında bu yaklaşımın değiştiğini ifade etmek güçtür. Uluslararası iklim müzakerelerinde Türkiye özel koşullar söylemine bağımlı kalarak sera gazı emisyonlarını azaltma noktasında somut hedefler ortaya koymaktan kaçınmaktadır. Paris Anlaşması’nın onaylanmaması da bu doğrultuda değerlendirilmesi gereken siyasi bir tutumdur. Türkiye’de devlet tıpkı çevre politikasında olduğu gibi iklim değişikliğini de kalkınma önceliğinin gerisinde konumlandırmaktadır. Bu bağlamda özellikle enerji ve büyüme politikaları ile cari açık sorunu da belirleyici olmaktadır. Konu yerel düzeyde ele alındığında da, yerel yönetimlerin bu alandaki çalışmaları merkeziyetçilik engeline takılmaktadır. Bu çerçevede Türkiye'de sınırlı sayıda ve öncü denebilecek belediyenin iklim değişikliğine yönelik politikaları da, merkezi yönetimin yukarıdan aşağıya müdahaleleri sebebiyle beklenen etkinliğe ve verimliliğe ulaşamamaktadır. Buradan hareketle, çalışmada elde edilen bulgulara dayanılarak, yukarıda ifade edilen farklı etmenler çerçevesinde Türkiye’nin sera gazı emisyon azaltım hedefine bağlı olarak, iklim değişikliği politikasının genel özellikleri ve sınırlılıkları incelenecek ve tartışılacaktır.

Anahtar Kelimeler: İklim Değişikliği, Uluslararası İklim Müzakereleri, Kalkınma, Enerji Politikaları, Yerel Yönetimler

\section{Abstract}

The agenda-setting of climate change policy in Turkey goes back to the acceptance process of the Kyoto Protocol. From this process, central administration begins to develop certain policies and measures at the same time to make institutional structures. In this work, the interest will be to question the

* Marmara Üniversitesi, Siyaset Bilimi ve Kamu Yönetimi Bölümü, ufuk.ozisik@marmara.edu.tr 
formulation and the implementation of a structured and integrated public policy on climate change in Turkey. In the literature, academics point out that until the Kyoto Protocol process, the question is conceived in a logic of foreign policy of the State. Unfortunately, this perception is far from being replaced since that date until today. Turkey relying on the narrative of "special circumstances" adopts a reticent approach vis-à-vis the sine qua non objective of international negotiations to reduce emissions of greenhouse gases. The non-adoption of the Paris Agreement continues and reinforces this positioning. In Turkey, the central administration, as in its environmental policy, prefers to focus its economic and industrial ambitions in the face of climate change emergencies. From this perspective, energy policies and development policies seem to determine and delineate any possible initiative regarding climate change policy. At the local level, the initiatives of local authorities come up against administrative centralization, a phenomenon which has reappeared and been reinforced since 2010. In this context, the central administration limits the voluntary actions and the capacity of local governments by topdown interventions. By referring to these various factors and issues, this work aims to examine the charasteristics and limits of climate change policy in Turkey, according to the objective of reducing emissions of greenhouse gases.

Keywords: Climate Change, International Climate Change Negotiations, Development, Energy Policies, Local Administrations

\section{Giriş}

Kyoto Protokolü sürecine kadar Türkiye'de devlet, iklim değişikliğini bir dış politika konusu olarak algılamış ve bu çerçevede sorunla ilgili konumunu ve eylemlerini şekillendirmiştir. Kyoto Protokolü'ne taraf olunmasından itibaren siyasal iktidar, hem bir takım strateji ve eylem planları hazırlamaya başlamış hem de bunların uygulanması ve yönetilmesi amacıyla kurumsal düzenlemeleri de hayata geçirmeye başlamıştır. Kyoto Protokolü’nün kabulünden günümüze uzanan dönemde atılan adımlara bakıldığında karşımıza parçalı, dağınık ve oturmamış bir kamu politikası ve özellikle de uygulama aşamasında etkinlik-verimlilik açısından sorunlu bir tablo çıkmaktadır. Bir yandan devletin iklim değişikliği sorununu uluslararası iklim değişikliği müzakerelerindeki konumu ve taleplerine koşut olarak konuyu uzunca bir süre bir dış politika konusu olarak algılaması, diğer yandan kalkınma politikası ve özellikle de enerji politikasındaki öncelik ve hedeflerin uluslararası müzakerelerde öncelikli hedef olarak kabul edilen sera gazı emisyonlarının azaltılmasını sağlayacak önlem ve tedbirlerin alınmasının önünde ciddi bir engel teşkil etmesi, sözü edilen olumsuz tablonun en temel sebepleri olarak ortaya konabilir. Türkiye’nin müzakerelerdeki “özel koşullarını” ileri sürerek somut azaltım hedeflerini ortaya koymaması ve bunlara ilişkin kayda değer eylemlerden kaçınması, Paris Anlaşması’nı onaylamaması, sera gazı emisyonlarını katlayarak artırması iklim değişikliği konusunda sürdürülebilir bir pozisyon olmaktan uzaktır. Küresel ısınma ile mücadelede uluslararası toplum, özellikle de yüksek düzeyde emisyonda bulunan gelişmiş ülkelere bakıldığında da bir takım iyi niyet beyanlarının ötesine geçilemediği ve kötü gidişi tersine çevirecek bir ilerlemenin ortaya konamadığı gözlemlenmektedir. Gelişmekte olan ülkeler tam da bu noktada gelişmiş ülkelerin küresel ısınmadaki tarihsel sorumluluklarına vurgu yapmakta ve kendilerinden önce bu ülkelerin dolaysız azaltım hedeflerini ortaya koymalarını buna uygun hareket etmelerini beklemektedirler. Buradan hareketle, uluslararası müzakereler ve anlaşmaların tek başına küresel ısınma ile 
mücadelede yeterli olamayacağına, bu mücadelede özellikle gelişmiş ülkelerde ulusal seviyede somut azaltım hedeflerinin ortaya konmasının önemine vurgu yapılmaktadır:

"Although an international agreement is a vital aspect of an effective global response to climate change, we cannot rely exclusively on international consensus as an impetus for action. No amount of discussion at an international level will be of any consequence if the countries mainly responsible for causing climate change do not make effective and radical responses to it. So, it is at the national-level in the developed countries that real progress first has to be made. And it is through decisive national leadership at this level that a global solution can eventually be induced (Giddens, 2008)

Gelişmiş ülkelerde dolaysız yoldan (direkt) emisyon azaltımına yönelik tedbirler ve politikalar (mitigasyon) ön planda iken, gelişmekte olan ülkelerde ve Brezilya, Çin, Hindistan ve Türkiye gibi yükselen piyasa ekonomilerinde ise uyum politikaları (adaptasyon) daha fazla ön plandadır. Almanya gelişmiş ülkeler arasında emisyon azaltımı yönünde en çarpıcı sonuçları elde etmiş ülkelerden biri olarak ortaya çıkmaktadır. Sera gazı emisyonuna en fazla neden olan enerji sektöründe bu ülkede son yirmi yılda önemli ilerlemeler kaydedilmiştir. 2000 yılında yenilenebilir enerji kaynaklarının toplam elektrik üretimindeki payı \%6,8 iken 2013 yılında bu oran \%25,4'e çıkmıştır. Nükleer santrallerin yarıdan fazlasının faaliyetlerine son verilmiştir. Sonuç olarak 19902013 döneminde Almanya emisyonlarını \%23,8 oranında azaltmayı başarmıştır. Bu bağlamda enerji verimliliğinin artırılması ve enerji arzında fosil yakıtlarının oranının azaltılmasına yönelik girişimler Almanya’nın iklim değişikliği politikasındaki en önemli hamleleri olarak görülebilir. Çin, Brezilya, Hindistan ve Türkiye gibi ülkelerde ise temel öncelik uluslararası iklim müzakereleri sonucu ortaya çıkabilecek dayatmacı/zorlayıcı somut azaltım hedefleri ve sorumluluklarından kaçınmaktır. Bu ülkeler ekonomik büyüme ve kalkınma hedefleri doğrultusunda giderek artan şekilde emisyonlarını da artırmaktadırlar. Bu ülkelerde iklim değişikliği politikalarında ortak yönlerden biri de bu hedefleri sekteye uğratmayacak şekilde eylemlerde bulunmalarıdır. Bir yandan yenilenebilir enerji kaynakları yatırımlarını artırırken diğer yandan enerji ihtiyacını karşılayan düşük maliyetli ancak kirletici kaynakların kullanımından vazgeçmemektedirler veya bunlarda önemli azalışlara gitmemektedirler. Uluslararası iklim rejiminin sunduğu teknolojik ve finansal desteklerden ve mekanizmalardan da yararlanarak asgari maliyetler ile çevreye duyarlı bir üretim altyapısını ve enerji sektörünü kurmak amacındadırlar.

Bir kamu politikasının varlığından söz edebilmek için o politikanın sorun alanında bulunan ve o sorundan etkilenen bir hedef kitlesi olması gerekmektedir. Bunlar kimi zaman belli toplumsal gruplar kimi zaman sektörel aktörler kimi zaman da bir takım çıkar grupları olarak karşımıza çıkmaktadır. Hedef kitleyi de aslında tayin eden o kamu politikasının niteliği, etki alanı ve hedefleridir. Diğer yandan sorunun çözümüne dair geliştirilen söylem ve anlam dünyaları ile normlar da o kamu politikasının niteliği ve kapsamı bağlamında açıklayıcıdır. Tüm bunlar ışı̆̆ında kamu politikasının ilgili olduğu sorun alanına ilişkin çözüm önerileri ve araçları ile bunları tatbik edecek kurumsal yapılanma da ortaya çıkar (Muller, 2013, s. 20-21). Türkiyede iklim değişikliği sorununa ilişkin kamusal eylemlerin bir bütünlük arz eden bir kamu politikası 
niteliğini kazanmış olduğunu ileri sürmek güçtür. Devletin bu konuya ilişkin net bir tanımı, etkin bir kurumsal yapılanması, değerler sistemi ve uygulama araçları sistemli bir biçimde vücut bulmuş değildir. İklim değişikliği, enerji ve kalkınma gibi diğer kamu politikaları ile kıyaslandığında halen öncelikli bir mesele haline gelmemiştir.

İşbu çalışmada, kamu politikası analizi çerçevesinde Türkiyede iklim değişikliğinin bir kamu politikası olarak incelenmesi hedeflenecektir. Türkiye çeşitli sektörlerde iklim değişikliği ile mücadelede dolaylı yoldan bir takım uyum tedbirlerini hayata geçirmektedir. Ancak bu eylemlerin bütüncül bir iklim değişikliği politikasının uzantıları olarak değerlendirilmesi mümkün olamamaktadır. çünkü Türkiye, küresel ısınma ile mücadelede uluslararası iklim müzakereleri çerçevesinde kendisinden beklendiği üzere somut bir emisyon azaltım hedefi ortaya koy(a)mamaktadır. Bu durum, Türkiye’deki iklim değişikliği politikasının kapsamına ve niteliklerine de etki etmektedir. Buradan hareketle bu çalışmada, iklim değişikliği sorununun algılanması, tanımlanması ve yönetilmesi çerçevesinde siyasi irade, kurumsal yapılanma, söylemler ve faaliyetler değerlendirmeye alınacaktır. Bu çerçevede, iklim değişikliği sorunu ilk olarak tarihsel perspektifte ele alınacaktır. Türkiye’de iklim değişikliği sorununa ilişkin algı ve değerler sisteminin takip ettiği yol çevre politikalarındaki hâkim algı ve söylemlerin devamlılığı üzerinden değerlendirilecektir. İkinci olarak, ulusal politikalara yön verme gücü olan uluslararası iklim müzakerelerindeki Türkiye'nin konumu, stratejisi ve talepleri ele alınacak, ulus üstü dinamiğin bu alanda Türkiye’ye olan yansımaları ve ulus üstü dinamiğin Türkiye tarafından nasıl algılandığı ve kullanıldığı ele alınacaktır. Üçüncü olarak, Türkiye’de var olan büyüme stratejisiyle enerji ve kalkınma politikalarının, iklim değişikliği ile ilintili olan diğer kamu politikaları olmaları sebebiyle iklim değişikliği politikasına nasıl etki ettikleri ortaya konacaktır. Bir ülkedeki iklim değişikliği politikası incelenirken merkezi yönetimlerin faaliyetlerinin yanında yerel yönetimlerin çalışmalarının ve bunların merkez ile olan ilişkilerinin de analiz edilmesi önem arz etmektedir. Dünyada küresel ısınmaya sebep olan emisyonlar yüksek oranda kentsel mekânlarda gerçekleşmektedir. İklim değişikliği ile mücadelede yerel yönetimlerin giderek artan işlevleri ve eylemleri söz konusu olmaktadır. Bu eylemler özerk faaliyetler olarak ortaya çıkabildiği gibi merkezi otoriteler ile koordinasyon sağlanarak da hayata geçirilebilmektedir. Ülkelerde var olan idari sistemler ve yönetim kademeleri arasındaki yapısal özellikler ile yerel/bölgesel yönetişim kapasiteleri bu eylemleri tayin edebilmektedir. Bu perspektifte, dördüncü olarak, iklim değişikliği politikasında Türkiyedeki yönetim anlayışı ve pratiklerinin belirleyici ve sınırlayıcı rolü ön plana alınarak konu, yerel yönetimlerin faaliyetleri ve bu düzlemde karşılaşılan sorunlar çerçevesinde tartışılacaktır. Tüm bu değerlendirmeler ışığında Türkiye’deki iklim değişikliği politikasını belirleyen farklı faktörler ortaya konmuş olacaktır.

Çalışmada, iklim değişikliği sorunu ile ilgili uluslararası müzakerelere ilişkin literatürden, istatistiki verilerden, Türkiye’de iklim değişikliğine ilişkin konumuzla alakalı olarak nitelendirilebilecek akademik yayınlardan, devletin resmi belgelerinden (yasal mevzuat, strateji ve eylem planları, kurumsal düzenlemeler) ve konuyla ilgili eylemlilik halinde olan yerel yönetimlerin çalışmalarından yararlanılacaktır. Ayrıca, konunun uzmanı olarak kabul edilebilecek iki akademisyen ve İstanbul'da Kadıköy Belediyesi’nden uzmanlarla gerçekleştirilmiş 
olan yüz yüze görüşmelerden edinilen bulgular da çalışmada değerlendirilecektir. Görüşülen uzman akademisyenlerin yayınlarına metin içinde referans verilmekle birlikte, her ikisinin de bu politikaya ilişkin süreçlerde aktif rol oynamaları (Uluslararası İklim Müzakereleri toplantılarına giden Türkiye Heyeti’nde bulunmak, politika oluşturma süreçlerine yaptıkları çalışmalar ile girdi oluşturmak, kamuoyunu konuyla ilgili aktif olarak bilgilendirmek vb.) sebebiyle kendileriyle özel olarak da görüşülmüş ve değerli bilgilere erişilmiştir. Kadıköy Belediyesi’nin tercih edilmesinde ise bu ilçe belediyesinin iklim değişikliği ile ilgili olarak eylemliliğinin ve çalışmalarının öncül nitelikte olması ve bu yöndeki pro-aktif kimliği rol oynamıştır.

\section{Kalkınmacı Geleneğin Gölgesinde Çevre Politikasından İklim Değişikliğine "Patika Bağımlılı̆̆ı"}

Kamu politikaları analizinde patika bağımlılı̆̆ ("path dependence") kavramı, herhangi bir politika alanında daha önceden, geçmiște alınmıș olan kararların ve hâlihazırda var olan siyasal/idari kurumların mevcut veya alınması planlanan kararlar üzerindeki belirleyici / sınırlayıcı etkileri üzerine odaklanmaktadır. Bu çerçeveden hareketle, politikanın tarihsel açıdan oluşturulma anındaki dinamiklere bir diğer ifade ile kamu politikasının "kökenlerine" bakmak hâlihazırdaki durumun açıklanmasında önem arz eder. Devletin ve kurumların bir politikaya ilişkin oluşmuş olan yerleşik düzen ve kavrayışlardan uzaklaşmak istememeleri, yani önemli değişikliklere gitme eğiliminde olmamaları da, olası değişimin çeşitli maliyetlerini (öğrenme süreçleri, kurumsal uyarlamalar veya yeni kurumsal yapılanma, mali yükler vb.) önemli riskler olarak görmelerine bağlanmaktadır. Kamusal alandaki bir soruna ilişkin aktörlerin ve özellikle devletin o sorunu tarihsel evrimi bağlamında nasıl algıladığı, nasıl tanımladığı, sürecin devamında oluşturulacak olan politikayı, o politikaya ilişkin kurumsal yapılanmayı ve politikanın uygulanma safhasını önemli ölçüde belirlemektedir (Boussaguet, Jacquot ve Ravinet, 2014).

Türkiyede iklim değişikliği politikası ile ilgili değerlendirmelerde bulunabilmek için öncelikli olarak Türkiye’nin çevre politikalarına ve bunların tarihsel gelişimine bakmak gerekmektedir. Nitekim iklim değişikliği sorunu ile çevre politikaları arasında sert bir ayrım yapmak günümüzde artık pek mümkün görünmemektedir. Bilakis, iklim değişikliği sorunu siyasal anlamda öncelikli olarak uluslararası toplumun çevreye ilişkin sorunlar çerçevesinde gerçekleştirdiği toplantılar sonucunda gündeme gelen bir konu olmuş ve küresel bir mesele olarak kabul görmeye başlamıştır. Bugün itibariyle iklim değişikliği ve çevre politikaları birbiriyle iç içe geçmiş, bir arada düşünülen meseleler olarak görülmelidir.

Türkiye’nin çevre sorunları bağlamında karnesi zayıflarla doludur. Türkiye, 1970’lerden bu yana bir çevre politikası geliştirme süreci içinde pek çok düzenlemeyi hayata geçirmiş bir ülkedir. Bununla birlikte çevre göstergelerine bakıldığında bazı sorunların azalmadan devam ettiği bazı sorunların artmaya devam ettiği görülmektedir. Dünya Ekonomik Forumu, Yale ve Columbia üniversiteleri tarafından hazırlanan ve 149 ülkeyi kapsayan 2008 Çevresel Performans Endeksi’ne göre Türkiye 72. Sırada yer almaktadır. Yine 235 ülkenin sınıflandırıldığı Çevresel Kırılganlık 
Endeksi'ne göre ise 62 ülkenin bulunduğu "çok savunmasız" kategorisinde yer almaktadır (Baykan, 2008). 2018 yılında Yale Üniversitesi bünyesinde gerçekleştirilen çevre performansı endeksinde ise Türkiye, endekste bulunan 180 ülke arasında 108. Sırada yer almaktadır. ${ }^{1} \mathrm{Bu}$ rapora göre Türkiye, Surinam, Paraguay ve Nijerya gibi ülkelerin gerisinde kalmış durumdadır.

Çevresel problemlerle ve bu problemlerin insan sağlığına ve yaşamına olumsuz etkileriyle 1970'li yıllarda tanışan Türkiye, çevresel çözüm politikalarını diğer ülkelere kıyasla oldukça geç benimsemiştir. 1970’li yıllarda ülkemizde henüz çevreci bir faaliyet veya oluşum bulunmazken, dünyadaki birçok ülkede çevresel düzenleme ve çevreci örgüt yapısının olması Türkiye’yi de harekete geçirmiş, bu yıllardan sonra çevre politikaları gelişmeye, çevreci kurum ve kuruluşlar ortaya çıkmaya başlamıştır (Kaya, 2012).

Türkiye’nin çevresel sorunlara eğilmede geç kalmasının nedeni, tıpkı diğer ülkelerde olduğu gibi baskın ekonomi politikaları olarak gösterilmektedir. Ekonomik büyümeden başka bir şey düşünmeyen bir sistem içerisinde çevre konusu ihmal edilmiş, çevresel sorunların çözümüne değil, çevrenin ekonomik büyümede nasıl kullanılabileceğine odaklanılmıştır. Bu noktada Türkiye'de 1950'li yıllardan itibaren iktidara gelen merkez sağ ve muhafazakâr partilerin özellikle "maddi” kalkınmacılığı önemsemeleri ve dolayısıyla kalkınmanın yarattığı ve yaratacağı dinamiklerin sosyal ve kültürel dönüşüm ile demokrasinin de gelişmesinin önünü açacağına dair olan inanç da hesaba katılmalıdır. ${ }^{2}$ Bu bakış açısı ülkemizde çevresel verilerin elde edilmesini, buna bağlı olarak da çevresel politikaların benimsenmesini de geciktirmiştir. (Saatçi ve Dumrul, 2011; Kaypak, 2011).

Türkiye gelişmekte olan bir ülke olarak çevre ve diğer kalkınma süreçleri arasındaki uyumsuzluğun negatif sonuçlarını yaşamıştır. Çevrenin diğer sektörlerle bütünlük arz eden bir yapı içerisinde ele alınmaması, çevre odaklı olmayan kalkınmaya öncelik tanınması zamanla çevresel değerlerin göz ardı edilmesine neden olmuştur.

Türkiye’de 1978-2003 yılları arasında çevre yönetiminin merkezi örgütlenmesi, '1978-Başbakanlığa Bağlı Çevre Müsteşarlığı, 1984-Çevre Genel Müdürlüğü, 1989-Çevre Müsteşarlı̆̆ı, 1991-Çevre Bakanlığı, 2003-Çevre ve Orman Bakanlığı’ olarak beş farklı şekil almıştır (Talu, 2004, s. 55). Sonrasında ise 2011 yılında ülkemizde birçok kurulun ve yapılanmanın Çevre ve Şehircilik Bakanlığı altında toplanması ve bakanlıkların yeniden düzenlenmesine ilişkin yasal düzenlemelerle çevre yönetimine ilişkin yapılanma daha merkezi bir yapıya kavuşturulmuştur (Toprak, 2012). İklim politikası çerçevesinde, Çevre ve Şehircilik Bakanlığı, Türkiye’nin iklim değişikliği odak noktasıdır ve tüm politika alanlarında koordinasyon ve strateji belirleme görevini yerine getirmektedir. Dolayısıyla bu alanların hepsi ile ilgilenmektedir. İklim değişikliği, kuruluş kanunundaki görevleri arasında ayrı bir başlık olarak yer alan Çevre ve Şehircilik Bakanlığı, "Küresel iklim değişikliği ve ozon tabakasının incelmesi ile ilgili tedbirlerin alınmasına yönelik

1 https://epi.envirocenter.yale.edu/epi-report-2018/executive-summary

2 https://www.sabah.com.tr/yazarlar/hanioglu/2017/12/24/kalkinmaciligin-turkiye-seruveni 
plan, politika ve stratejileri belirlemek amacıyla diğer kurum ve kuruluşlarla koordinasyon sağlamakla” görevlidir (Şahin, 1994, s. 94).

$\mathrm{Bu}$ dönemle kesişen bir diğer süreç de Türkiye’nin Avrupa Birliği (AB)'ne üyelik müzakerelerine başlaması ve bu doğrultuda hayata geçirilen uyumlaştırma politikalarına işaret etmektedir. AB’ye uyum süreci, Türkiye'deki çevre politikaları ve özelde de yerel yönetimlerin çevreyle ilgili faaliyetleri üzerinde önemli etkilerde bulunmuştur. Türkiye’nin $\mathrm{AB}$ ile bütünleşmesi süreci, çevre politikalarına önemli katkılar vermiş ve $A B$ çevre müktesebatıyla uyumlaşmayı sağlamak için var olan düzenlemelerde bazı değişikliklere gidildiği gibi aynı zamanda yeni yönetmelikler çıarılarak AB'nin çevre alanındaki düzenlemeleri iç hukuka uyarlanmışıır (Yıldırım ve Budak, 2010)

Baştan bu yana çevre politikasını şekillendiren söylemler, çevre-kalkınma ikilemiyle karşılaşılan hemen her bağlamda kalkınmaya öncelik veren bir nitelikte olmuşlardır. Bu söylemlerin hem çevre politikasının kurumsallaşmasını hem de uygulamayı büyük ölçüde şekillendirdiği görülmektedir (Orhan, 2014, s. 96). Orhan’a göre, Cumhuriyet dönemi boyunca sanayileşme aracil ğıyla kalkınma hedefine ulaşmaya çalışan ve ciddi bir yukarıdan-aşağıya modernleşme geleneğine sahip olan Türkiye için çevre koruma çabaları "ancak kalkınma çabalarını engellememesi kaydıyla" kabul edilebilecek bir çerçevede ele alınmıştır. Gelişmekte olan bir ülke olarak Türkiye’nin sanayileşme ve kalkınmaya zarar verecek çevre politikalarını kabul etmeyeceği belirtilmiştir. Türkiyéde çevre politikalarının oluşturulmaya başlandığı noktada çevre ve kalkınmanın birbirini dışlayan kategoriler olarak ayrı ayrı ele alındığı, aralarında bir üstünlük ilişkisi kurulduğu ve kalkınmanın öncelik sahibi olduğu bir anlam çerçevesinden bahsedilebilir (Orhan, 2013, s. 16).

1980 'lerin çevre politikası düzenlemelerini şekillendiren söylemlerin de büyük ölçüde 1970'lerin bakış açısını yeniden ürettiği görülür. 1983 yılında yayınlanan Çevre Kanunu incelendiğinde aynı ayrımın ve ilişkilendirmenin orada da yapılmış olduğu gözlemlenir. Benzer bir şekilde çevre ve kalkınma ayrımı yapıldığı ve çevre korumanın kalkınmayı engellemeyecek bir şekilde gerçekleştirilmesi bir hedef olarak yasaya konulmuştur (Orhan, 2013, s. 17). Türkiye’de iklim değişikliğiyle mücadelede 2872 sayılı Çevre Kanunu olmazsa olmazlardandır. Bu kanun temel kanun niteliğindedir ve bugüne dek çıarılan onlarca yönetmelik ve bu yönetmeliklere dayanılarak çıkarılan onlarca tebliğ ve genelgeye dayanak oluşturmaktadır. 2872 sayılı Kanun bugüne kadar pek çok değişikliğe uğrasa da en kapsamlı değişiklik 2006 yılında 5491 sayılı Kanun ile yapılan değişikliktir. Bu Kanun ile otuza yakın madde değişmiş, ona yakın yeni madde eklenmiştir. Bu değişikliğin gerekçesi olarak 1983 yılında çıkarılan Kanunun günün ihtiyaçlarına cevap verememesinin ve çevre sorunlarının daha da artmasının etkili olduğu belirtilmiştir. Yapılan değişikliklere bir örnek olarak adli ve idari yaptırımların ceza fiillerinin yeniden düzenlemesi gösterilebilir. Bu kapsamda, iklim değişikliği açısından önemli olan hava kirliliğine sebep olan ve baca gazı emisyonu yaratacak işletmeleri izinsiz açan ya da belirlenen miktardan fazla emisyona neden olanlara idari para cezası, bu konuda yanlış ve yanıltıcı bilgi verenlere ise hapis cezası öngörülmüştür. Bunun gibi pek çok değişiklik 2006 yllında yapılan düzenlemeyle 
Çevre Kanununa eklenmiştir. Çevre Kanununda 2006 yılında yapılan değişikliklerden biri de çevre katkı payı alınması, diğer gelirler ve bütçe ödenekleri hakkındaki 18. Maddede olmuştur. Bu düzenleme ile iklim değişikliği ile mücadele çalışmaları için Bakanlık bütçesinden ödenek öngörülmesi hükme bağlanmıştır. Bu kapsamlı değişikliklerden sonra 2872 sayılı Kanunda kapsamlı bir değişiklik olmamıştır. Kanunun Genel Kurul görüşme tutanakları incelendiğinde gerek iktidar, gerekse muhalefet partisi milletvekilleri tarafından iklim değişikliğinin varlığı ve bununla mücadele edilmesi gerektiği konularında hemfikir oldukları anlaşılmaktadır. Ancak Kanunun iklim değişikliği ile mücadelede yeterliliğini sorgulayan milletvekili olmamıştır. Görünen odur ki; iklim değişikliği daha çok hava kirliliği, su kirliği, atık sorunları gibi sadece bir çevre sorunu olarak algılanmakta, çok boyutluluğu ve çok sektörlülüğü görülmemektedir. ${ }^{4}$

Sürdürülebilir kalkınma kavramı, ilk kez, 1987 yılında Dünya Çevre ve Kalkınma Komisyonu’nca hazırlanan Brundtland Raporunda "Bugünün gereksinimlerini, gelecek kuşakların gereksinimlerini karşılama yeteneğinden ödün vermeden karşılayan kalkınma” olarak tanımlanmıştır. ${ }^{5}$ Brundtland Raporunun yayınlanması sonrasında ve özellikle Rio Konferansını ${ }^{6}$ takip eden dönemde sürdürülebilir kalkınma, başlangıçta bağlayıcı olmasa da zaman içinde, önemli bir çevre politikası söylemi olarak Türkiye’deki çevre politikalarını etkilemeye başlamıştır. Bu dönem sürdürülebilirlik ve sürdürülebilir kalkınma söyleminin gündeme geldiği, yükseldiği bir dönem olmuştur. Ancak bu süreçte de sürdürülebilirlik ve sürdürülebilir kalkınma oldukça sınırlı bir çerçevede ele alınmıştır. Sürdürülebilirlik hedeflerine ulaşmak için hayata geçirilmesi gereken politikaların entegrasyonu, paydaşların karar alma ve uygulama süreçlerine katılımı ve kalkınmanın daha farklı bir perspektifte ele alınmasını gerektiren politika ilkelerinin hayata geçirilmesi sürecinde önemli sorunlar yaşanmıştır. Dönemin politikacılarının söylemlerine bakıldığında çevreyi koruma kalkınmanın bir ön koşulu olarak görülmüş ve bir çeşit ekolojik modernizasyon projesi olarak, maliyet azaltıcı ve rekabetçiliği arttırıcı ve kalkınma için gerçekleştirilmesi gereken bir proje olarak sunulmuştur (Orhan, 2013, s. 18)

Pierson'a göre patika bağımlılı̆̆ında dört belirleyici etken bulunmaktadır: Bunlardan ilki siyasetin kolektif yani birden çok aktör ve yapının ortak üretimi olduğu olgusudur. İkincisi, siyasette var olan kurumların aktörlerin düşünce sistemleri ve eylemleri üzerindeki belirleyici ve sınırlayıcı etkisidir. Üçüncü olarak siyasal iktidarın niteliği ve nasıl paylaşıldığıdır ve burada herhangi bir politika alanındaki egemen iktidar yapıları ve bunların belirleyiciliği üzerinde durulur. Dördüncü olarak da siyasetin karmaşık ve öngörülemez doğasıdır. Burada da politikada yaşanabilecek değişimlerin kısa vadeli politik hedeflere bağlı olduklarına vurgu yapılır. Ayrıca,

4 https://kureseldenge.org/wp-content/uploads/2016/08/TBMM_ve_iklim_degisikligi_raporu.pdf (63-64)

5 http://www.mfa.gov.tr/surdurulebilir-kalkinma.tr.mfa

61992 yılında Brezilya’nın Rio de Janeiro şehrinde Birleşmiş Milletler Çevre ve Kalkınma Konferansı düzenlenmiştir. Rio Zirvesi olarak da bilinen bu konferans, 108’i devlet başkanlı̆̆ı düzeyinde olmak üzere 172 ülkenin katılımıyla gerçekleşmiştir. İki hafta süren bu konferansın hedefi, küresel ölçekte çevre sorunları ile mücadele ve sürdürülebilirlik olgusu arasında bağları güçlendirmektir. Sürdürülebilirlik olgusunun ön plana çıktı̆̆ Zirvede, Biyolojik Çeşitlilik, İklim Değişikliği ve Çölleşme ile Mücadele konularında 21. yüzyıl için yol haritası niteliğinde 3 sözleşme imzaya açılmıştır (BM Biyolojik Çeşitlilik Sözleşmesi, BM Çölleşme ile Mücadele Sözleşmesi, BM İklim Değişikliği Çerçeve Sözleşmesi) 
iktidarı elinde bulunduranların katı kurumsal düzenlemeler ve planlamalar ile hem kendilerini güvence altına almaya çalıştıklarına hem de kendilerinden sonra gelecek yöneticilerin siyasetlerini sınırlandırmak istemelerine vurgu yapılır. Bu dört unsur çerçevesinde politika değişikliklerinin sinırlılıkları açıklanmaya çalışılmıştır. (Pierson, 2000, s. 257).

Türkiyede çevre politikalarının değerler sistemine, normlarına, yasal mevzuatına, kurumsal örgütlenmesine ve bu politikaları kuşatan söylemlere bakıldığında çevrenin kalkınma politikalarının önceliklerinin gölgesinde kaldığını söylemek mümkündür. Gelişmekte olan ülke konumunun getirmiş olduğu ekonomik öncelik ve hedefler, bütünleşik ve somut politika kurum ve araçlarıyla donatılmış bir çevre politikasının oluşmasına engel oluşturmuştur. Bu ekonomik öncelikler ve hedefler, çevre politikası alanında var olan sivil toplum yapılarının ve diğer paydaşların politika süreçlerinde kamu ve özel sektör aktörlerinin gerisinde kalmasına neden olmuştur. Kamu politikalarında fikirler ve söylemlerin karakteristik özelliklerinin, ekonomik çıarlar ve onların taşıyıcılarının oluşturduğu egemen ittifaklardan bağımsız düşünülemeyeceği hesaba katıldığında, Türkiye'de çevresel duyarllık ve önceliklerin politika oluşturma sürecinde kamu ve özel sektörün kalkınmaya yönelik girdilerinin gerisinde kaldığı söylenebilir. Bu durum, ülkenin son dönemde büyüme stratejisinde öne çıkarılan inşaat sektörünün ekonomideki işlevi ve yoğunluğuna bakıldığında da görülebilir. Nitekim Çevre ve Şehircilik Bakanlığı’nın faaliyetlerine bakıldığında, kentsel rantlara dayalı olarak inşaat sektörüne verilen ağırlığın çevresel politikaların önünde olduğu gözlemlenmektedir. Bu durumu AB’ye uyum sürecinde yaşanan kısitlı gelişmeler de tersine çevirememiştir. Uluslararası iklim müzakereleri ve bu müzakerelerin dönüștürücü etkisi karşısında da Türkiye’nin geçmişten bugüne uzanan kalkınmaya yönelik önceliklerinin hâkim konumunun sarsılmadığını ve çevre politikasında çevresel öncelik ve hedeflere yönelik önemli değişikliklerin gerçekleşmediğini ileri sürmek mümkündür. Böylesine bir değişikliğin birçok yansıması ve maliyeti söz konusu olacaktır. Öncelikli olarak kalkınma-çevre ikileminde hâlihazırda var olan devlet-sermaye çıkar birlikteliğinin farklı aktörleri politika süreçlerine dâhil edecek şekilde yeniden tasarlanması gerekecektir. Türkiyede birçok $A B$ ülkesinde var olduğu şekliyle bir siyasi "yeşiller" partisi veya oluşumu bulunmamaktadır. ${ }^{7}$ Bu minvalde geçmişte ortaya çıkmış olan bir takım oluşumlar AB ülkelerindeki örneklerle de kıyaslanamayacak derecede cılız oluşumlar olarak kalmışlar, birer baskı unsuruna dönüşememişler ve günümüze uzanamamışlardır (Duru, 2013). Başkanlık sistemine geçişle birlikte yönetimde merkeziyetçiliğin ve yukarıdan aşağıya dinamiklerin güç kazandığı bir düzlemde bu alandaki sivil toplum yapılarının ve diğer paydaşların yönetişim mantığına dayalı olarak politika yapım süreçlerine dâhil edilmeleri de tartışmaya açıktır ve pek olası görünmemektedir. Bütün bunların yanında bir diğer maliyetin de, çevresel önceliklerin dikkate alınacağı bir kalkınma ve büyüme anlayışının üretim maliyetlerine getireceği yük olacağ ileri sürülebilir. Türkiye’nin orta-uzun vadeli ekonomik gelişme hedefleri ve yatırım planları düşünüldüğünde (örneğin: 2023, 2053, 2071 hedefleri, Kanal İstanbul Projesi ve diğer) "yeşil" ve "sürdürülebilir" bir kalkınma anlayışına geçişin hem siyasi hem de ekonomik anlamda maliyetinin siyasi iktidar tarafından pek de olumlu algılanmayacağını öngörmek çok da zor değildir. Tüm bu değerlendirmeler ışığında, geçmişten bugüne uzanan söylemlerin, ideolojik

7 https://yesilgazete.org/blog/2009/08/25/turkiye-de-yesil-hareketin-bolunmuslugune-dair/ 
yaklaşımların ve ekonomik çıkarların gölgesinde ortaya çıkmış statükonun çevre politikasının bir uzantısı olarak değerlendirebileceğimiz iklim değişikliği politikasında da kendisini "yerleştirdiğini” ileri sürmek mümkün olacaktır. İklim değişikliği politikasında Türkiyéde var olan problemlerin kaynağında bu statükonun ve patika bağımlılığının etkisi önemlidir. Bu statükonun dayandığı en önemli sacayaklarından biri de Türkiye’nin uluslararası müzakereler çerçevesinde geliştirmiş olduğu özel koşullar söylemidir.

\section{Kyoto Protokolü’nden Paris Anlaşması’na Türkiye’nin Pozisyonu ve Stratejisi: “Özel Koşullar” Söylemi ve Sınırlılıklar}

Ulusal seviyede bir kamu politikasının ortaya çıkışı, gündeme gelmesi, oluşturulması, kurumsallaşması ve tabii ki uygulanması noktasında iç dinamiklerin yetersiz kaldığı durumlarda ulus-altı ve/veya ulus-üstü dinamiklerin dönüştürücü ve katalizör işlevi görmeleri olgusu kamu politikası analizlerinde ortaya çıkabilmektedir (Hassenteufel, 2009, s. 255). Avrupa Birliğìne üyelik hedefiyle birçok kamu politikasında gerçekleştirilen uyumlaştırma çalışmaları ve Avrupalılaşma süreçleri bunlara örnek olarak gösterilebilmektedir. Ulus-üstü yapıların ulusal yönetim ve politika seviyesinde koşulluluk esasına da dayalı olarak değişimlere yol açabildiği, bunun da ötesinde belirli kamu politikası alanlarında ülkelerin birbiriyle benzeşen (convergenceyakınsama) uygulama ve anlayışları benimseyebildiği bilinmektedir (Hassenteufel, 2009, s. 258). Çevre ve iklim değişikliği politikaları söz konusu olduğunda, Türkiye’nin her iki alanda da kısıtlı da olsa mesafe kat etmesinde $A B$ sürecinin ve Birleşmiş Milletler çatısı altında gerçekleștirilen uluslararası iklim müzakerelerinin önemli işlevler gördüğü ifade edilebilir. Hava kirliliği, su kirliliği ve atıklar başta olmak üzere Türkiye, $A B$ ile çevre sektöründe önemli ölçüde mevzuat uyumunu sağlamış durumdadır. Son dönemde gündeme gelen diğer çevre politikalarına göre görece daha etkin bir şekilde hayata geçirilen "sıfır atık" politikası bu alandaki sınırlı sayıdaki iyi örneklerden biridir.

İklim değişikliği özelinde ise 1992 Rio Konferansı̉ndan başlayarak, Türkiye uluslararası müzakerelere düzenli olarak katılmış, bu süreç zarfında 2009 yılında Kyoto Protokolünü de onaylayarak protokole taraf ülke olmuştur. Tam da bu noktada, Kyoto Protokolü sürecine gelene dek Türkiye’nin iklim değişikliği politikasını bir dış politika meselesi olarak gördüğünü de ifade etmek gerekir. Bu anlayışın güncel söylem ve uygulamalara baktığımızda değiştiğini ileri sürmek de pek olası değildir.

(...)Türkiye’nin çevre koruma alanındaki temel mevzuatı 1983'te kabul edilen ve 2006'da kapsamlı bir değişikliğe uğramış olan 2872 sayılı Çevre Kanunu’dur. Bu kanunda iklim değişikliği sadece Çevre Kirliliği Önleme Fonu ve bütçe ödenekleriyle ilgili bir maddenin 2006'da değiştirilen yeni şeklinde geçmektedir. Kanunda iklim değişikliği konusunda Bakanlı̆̆ görevlendiren asıl hükmün 3. Maddenin 1 bendindeki "Bölgesel ve küresel çevre sorunlarının çözümüne yönelik olarak taraf olduğumuz uluslararası anlaşmalar sonucu ortaya çıkan ulusal hak ve yükümlülüklerin yerine getirilmesi 
için gerekli teknik, idarî, malî ve hukukî düzenlemeler Çevre ve Orman Bakanlığı’nın koordinasyonunda yapılır” hükmü olduğu görülür. Bakanlığın kuruluş kanununda da (1991 ve 2003'te mevcut olan bir maddeyle) Madde 2/m’de "Bakanlığın görev alanına giren konularda uluslararası çalışmaların izlenmesi ve bunlara katkıda bulunulması maksadıyla ulusal düzeyde yapılan hazırlıkları ilgili kuruluşlarla işbirliği halinde yürütmek” görevi Çevre ve Şehircilik Bakanlığı’na verilmektedir. Bu da Bakanlığın iklim değişikliği konusundaki koordinasyon görevinin, meselenin bir uluslararası anlaşma konusu olmasından ileri geldiğini göstermektedir. Bu durum iklim değişikliği konusunun kamu idaresinin gündemine giriş biçimiyle son derece uyumludur ve kimi bakanlıklarda iklim değişikliği konusunun neden dış ilişkiler ve/veya Avrupa Birliği ile ilgili birimler tarafından ele alındığını açıklamaktadır. İklim değişikliği Türkiye kamu idaresi için kuraklık ve benzeri etkileriyle ulusal düzeyde ekolojik, ekonomik ve sosyal sorunlar yaratan bir çevre sorunu olmaktan çok ve ondan önce, uluslararası anlaşmalardan doğan yükümlülükler nedeniyle politika geliştirilen bir meseledir (Ümit Şahin: 2014).

2015 yılında Paris'teki Taraflar Konferansı’nda kabul edilen Paris Anlaşması ise Türkiye tarafından imzalanmış ancak henüz onaylanmamıştır. Bu zaman zarfında, özellikle Kyoto Protokolü’ne taraf olunmasını takiben, AB sürecinin de katkılarıyla Türkiye, İklim Değişikliği ${ }^{8}$ ve Hava Yönetimi Koordinasyon Kurulu'nu (2013) oluşturmuştur. Bu sürece paralel olarak, 2011-2023 Ulusal İklim Değişikliği Eylem Planı, 2010-2023 İklim Değişikliği Stratejisi, 2011-2023 İklim Değişikliği Uyum Stratejisi ve Eylem Planı da hazırlanmıştır. Bu düzenlemelerin hayata geçmesinde temel belirleyici etken BM İklim Değişikliği Çerçeve Sözleşmesi’nin (BMİDÇS) devreye girmesi ve bu sözleşmeye bağlı protokollere imza atılmış olmasıdır. Bununla birlikte, Türkiye, Kyoto Protokolü ve Paris Anlaşması dahil olmak üzere, bu anlaşmalara taraf olan diğer ülkelerden farklı olarak öne sürdüğü özel koşullardan hareketle sayısallaştırılmış emisyon sınırlandırma / azaltım taahhüdünde bulunmamıştır. İşbu “özel koşullar” söylemi ve bunun üzerine bina edilen siyasal pozisyon, Türkiye’nin iklim değişikliğine ilişkin uluslararası müzakere süreçlerinin doğurabileceği atılımlardan da önemli ölçüde imtina etmesine sebep olmuştur. Türkiye’nin sürekli olarak dile getirdiği “özel koşullar” söylemi ve buna bağlı olarak yaşadığı ataletin kökeninde Birleşmiş Milletler İklim Değişikliği Çerçeve Sözleşmesi (BMİDÇS)'nin oluşum sürecinde gerçekleştirilen sınıflandırmada "yanlış” yerde konumlandırılması bulunmaktadır. Dışişleri Bakanlığı’nın web sitesinde Türkiye ve BMİDÇS ilişkisini anlatan başlıkta bu durum süreç ortaya konularak açıkça belirtilmiştir?'

Türkiye’nin özel koşullar söylemini dayandırdığı durum, bir OECD ülkesi olması nedeniyle EK-1 ülkelerinin 1. Grup kategorisine yerleştirilmesidir. Türkiye’nin müzakerelerdeki pozisyonu tam da bu noktada, teknolojik ve finansal destek mekanizmalarından yararlanamaması sorununu doğurmaktadır. Özel koşullar söylemi, Türkiye’nin aslında halen gelişmekte olan bir ülke

8 Türkiye BMİÇS’ye taraf olmadan önce kurumsal yapılanmaya gidilmiş ve 2001/2 sayılı Başbakanlık Genelgesi’yle İklim Değişikliği Koordinasyon Kurulu (İDKK) oluşturulmuştur. İDKK, 2013 yılında yeniden yapılandırılarak İklim Değişikliği ve Hava Yönetimi Koordinasyon Kurulu (İDHYKK) adını almıştır. 
olduğunu iddia etmesine ve de dolayısıyla müzakerelerin öngördüğü sorumluluklar çerçevesinde diğer EK-1 ülkeleri gibi somut azaltım hedefleri ortaya koymasının adilane olmayacağı söylemine dayanmaktadır. Ayrıca, gelişmekte olan ülkelere yönelik fonlardan, ulusal emisyon azaltımına destek olacak teknolojik ve finansal destek mekanizmalardan yararlanamaması da Türkiye’nin bu söyleminde önemli bir etkendir. Örneğin, Güney Kore, Meksika ve Çin gibi benzer koşullara sahip ülkeler Yeşil İklim Fonu ${ }^{10}$ 'ndan faydalanabilirken Türkiye bu fondan yararlanamamaktadır. Diğer yandan Türkiye'den gelişmiş ülke statüsünde bulunması sebebiyle gelişmekte olan ülkelere finansal ve teknolojik destek vermesi de beklenmektedir. Türkiye’nin iklim değişikliğine ilişkin uluslararası müzakerelerdeki sorunsalı ve pozisyonu temel olarak bunlara dayanmaktadır. Nitekim Marakeş'teki Taraflar Konferansı ve devamındaki süreçte bu yönde bir takım kazanımlar elde edilmiş olsa da 2015 yılında Paris’te gerçekleşen Taraflar Konferansı ve Paris Anlaşması çerçevesinde de, Türkiye’nin anlaşmayı onaylamamasının nedeni olarak yine aynı sorunsalın ortada bulunduğunu söylemek gerekir.

Bakan Albayrak, Türkiye’nin Paris İklim Anlaşması’nı TBMM’den geçirmemesine yönelik bir soruyu yanıtlarken şu ifadeleri kullanmıştır:

“Türkiye bu anlaşmayı imzaladı ancak Parlamentosundan geçirmedi. Sebebi şu; Türkiye gelişmekte olan bir ülke olarak, iklim değişikliği konusunda gelişmiş ülkeler gibi finansal destek verme yükümlülüğü kalkmadığı sürece Türkiye bu noktada muhatap değil. (...) Hem Avrupa’nın Amerika’nın dünyayı en çok kirleten ülkelerinin dörtte biri kadar kirleteceğim ben ama diyecekler ki 'Türkiye sen gelişmiş ülkesin.' Hiçbir anlamda 'gelişmiş ülke' demeyecekler, bu arada 'Siz hala gelişmektesiniz' diyecekler ama burada finansal yük yükleneceğiniz zaman böyle. Fransa, Almanya gibi ülkelerin ilgili devlet başkanlarının birçoğu sözlü bir şekilde bize taahhüt vermelerine rağmen hala daha bunu gerçekleştirmediler. Bunu gerçekleştirmeden Türkiye olarak biz, gelişmekte olan bir ülke olarak niye bu yükümlülüğü çekelim? Bu gerçekleşene kadar haklı olduğumuz bu mücadelemiz devam edecek.” (21.11.2017)

Çevre ve Şehircilik Bakanı Murat Kurum da 2018'deki 24. Taraflar Konferansı'nda benzer ifadeleri kullanmıştır:

“İklim değişikliğiyle mücadele konusunda uluslararası finans kaynaklarına ülkemizin erişiminin sağlanmasını talep etmekteyiz. Burada en büyük beklentimiz, Türkiye’nin iklim sistemi altında hakkaniyetli bir konuma sahip olması ve özellikle Yeşil İklim Fonu altındaki finans desteğine erişimimizi sağlayacak kararın Polonya’da alınmasıdır."

Benzer ifadeleri İklim Değişikliği ve Hava Yönetimi Koordinasyon Kurulu'nun üyesi olan TOBB’un Başkanı Rifat Hisarcıklığlu da kullanmıştır: 
"Böylece iklim değişikliği ile mücadelede yeni bir evreye geçmiş olduk. Aslında ilk defa 195 ülkenin tamamını kapsayan, evrensel bir iklim değişikliği ile mücadele anlaşması söz konusu. Paris Anlaşması, taraf olacak tüm ülkelere bağlayıcı hükümler getiriyor. Dolayısıyla taraf ülkelerin, çevre, enerji, yatırım, kalkınma gibi politikalarında orta ve uzun vadede değişikliğe gitmesi gerekiyor. Bu noktada ülkemiz için bir sıkıntı söz konusu. Türkiye en baştan itibaren, bu müzakerelere 1. grup ülkeler arasında kabul edilerek dâhil oldu. Ne yazık ki Paris'te Türkiye’nin tüm taleplerine rağmen, ne karar metnine, ne de antlaşma metnine, Türkiye'nin özel durumunun yazılmasına müsaade edilmedi. Umarız önümüzdeki yıl Fas'ta yapılacak konferansta bu husus bir çözüme kavuşur. Aksi halde yeni anlaşmanın yürürlüğe girmesiyle birlikte, Türkiye’ye karbondioksit emisyonlarında azaltım yükümlülüğü getirilecek. Bunun sonucunda da, kurulması öngörülen 'Çevre Fonu'nda, yararlanan ülke değil, 'donör' ülke konumunda bulunması ihtimalini doğacak. Yani gelişmiş sanayi ülkeleri gibi mali yükümlülük altına gireceğiz. Oysa gelişmiş sanayi ülkeleri ile gelişmekte olan ülkelerin iklim değişikliği konusunda tarihsel sorumlulukları farklıdır. Ülkemiz bu global mücadele alanında elbette sorumluluğunu yerine getirecektir. Ama hakkaniyet beklemek de hakkımızdır." (11.01.2016, Yeni Asya)

Siyasetteki problemlerin çözümüne yönelik ortaya çıkan kamu politikaları beraberinde bir anlamlandırma ve meşruluk sürecini de beraberinde getirmektedir. Buradan hareketle kamu politikasının ilişkili olduğu sorun alanının nasıl tanımlandığına ve nasıl algılandığına dair o politika alanındaki aktörlerin söylemlerinin analizi önem kazanmaktadır. Bu noktada, söylemler birbiriyle yarışmaktadır ve bunlar arasında bir veya birkaçı çeşitli ikna, istişare, manipülasyon veya bir takım iktidar araçlarının kullanılması suretiyle egemen konuma gelmektedir. Söylemler üzerinden kurulan aktör koalisyonları burada belirleyici olmaktadır. Elbette, söylemler üzerinde kurulan bu koalisyonların ortak çıkarların üzerinde belirginleştiğini belirtmek gerekir (Hajer, 1993, s.44). Bu koalisyonlar, kamu politikası analizinde "politika toplulukları" olarak da tanımlanmaktadır (Fischer, Miller, Sydney, 2007, s. 137). Enerji Bakanı ve TOBB Başkanı’nın yukarıdaki ifadelerine bakıldığında iklim değişikliği politikası bağlamında temel kaygı ve önceliğin Türkiye’nin özel koşulları olduğunu görmek mümkündür. Devletin ve sermaye sınıfı aktörlerinin bu noktada ortak ekonomik hedef ve çıkarlara dayalı bir söylem birliği içinde olduğu ortadadır. Oysa iklim değişikliği konusunda devletin ve sermayenin söylemlerinden farklı tespit, öneri ve eleştirilerde bulunan başka aktörler de bulunmaktadır. Çevre örgütlerinin ve sivil toplum kuruluşlarının iklim değişikliği ile ilgili farklı söylem ve çağrıları yönetici elitin söylemlerinde ve ajandasında kendine yer bulamamaktadır. Bunun en önemli sebepleri olarak bu görüş ve önerilerin muhalif nitelikte olması ve siyasi iktidar ile bağlantılarının diğer aktörlere göre zayıf olması ifade edilebilir.

Yukarıdaki ifadelerden de anlaşılacağı üzere, Türkiye’nin uluslararası müzakerelerdeki bu pozisyonu ve söyleminin içeriğine ve niteliğine baktığımızda, bir "adaletsizlik" ve "mağduriyet” algısı da göze çarpmaktadır. Ümit Şahin bu durumu şöyle özetlemektedir: 
“Türkiye’nin iklim değişikliği politikaları ile çelişen ideolojik bir bakış açısı bulunmaktadır. Nedir bu? Türkiye’nin aslında Batı tarafından sömürülmüş olan, işte kalkınması engellenmiş olan yıllarca haksızlığa uğramış bir ülke olduğuna inanılıyor. Yarı milliyetçi yarı antiemperyalist bir bakış açısı. İklim değişikliğine sebep olan Batıdır, Türkiye’nin artık kalkınmaya hakkı vardır düşüncesi... "Onlar kirleterek yaptılar biz de kirleteceğiz şimdi”... Düşünce budur. Gelişmekte olan ülkelerin müzakerelerdeki argümanı buydu gelişmiş ülkelere karşı... Türkiye burada sert değil ama diğer ülkeler Paris sonrası bu pozisyonu biraz esnetmeye başladılar Türkiye bunu henüz yapmadı Türkiye Paris’i onaylamadı. Finansman alamıyoruz söylemi vs. Biz geri bırakıldık, Batı tarafından az gelişmiş ülke haline getirildik... Bir de üstüne EK-1'e soktular bizi daha da haksızlık yaptılar... Finansal desteklerden faydalanamıyoruz. Bunu algılama biçimi, haksızlığa uğramışlık duygusu...” (Ümit Şahin ile mülakat - 19.03.2019)

Türkiye'nin uluslararası rejim ve müzakerelerdeki bahsi edilen konumu, pozisyonu ve taleplerine bakıldığında ulus üstü dinamiğin, Türkiye’de iklim değişikliği politikasına ve buna dair hedeflere yönelik olumlu etkilerde bulunduğunu ileri sürmek pek olası görünmemektedir. Türkiye, uluslararası müzakerelerde kendisine haksızlık yapıldığını iddia ederek hem bu müzakerelerde aktif rol oynayamama gibi bir sorunla karşılaşmakta, hem de emisyon azaltımına yönelik somut hedefler belirleme ve eylemlerde bulunma noktasında çekimser veya isteksiz bir tavır takınmaktadır. Dolayısıyla uluslararası dinamiğin, Türkiye’de iklim değişikliği konusunda itici bir güç olmaktan uzak olduğu ifade edilebilir. Paris İklim Anlaşması’nın onaylanmamasının da Türkiye'yi yakın gelecekte özellikle finansman ve teknolojik destekler konusunda daha ileri düzeyde zora sokabileceği ifade edilmektedir:

“(...) Teori şu, eğer 2020'de, Paris anlaşması tam anlamıyla yürürlüğe girdiği zaman biz Paris’e taraf olursak, biz EK-1 ülkesi olarak gelişmiş ülke olduğumuzu kabul etmiş olacağız ve bütün iklim finansmanından mahrum kalacağız. Ben bunu herkese sordum. Bu nerden çıktı deniyor. Böyle bir teori doğru değil. Bu tez Türkiye’nin kendi kendine ürettiği bir tez. Tam tersine eğer Türkiye, hala 2020'de Paris'i onaylamamış ise, onaylamayan ülkelere krediler kesilebilir bu olasılık var aslında. Bu gerçeğe dönüşebilir. Türkiye iki arada bir derede kalmış durumda. Bir nedeni budur anlaşmanın onaylanmamasının. Bir de Clean Technology Mechanism-CTM (Temiz Teknoloji Fonu ${ }^{11}$ ) CTM'den faydalanamıyor Türkiye bu temiz teknoloji transferinden... Ona yapılacak bir şey yok EK-1 ülkesi iseniz yararlanamazsınız. (...) Bizimkiler diyor ki biz EK-1 olarak onaylarsak mutlak azaltım hedefini alamayız. Enerji Bakanlığı, bunu kullanarak bloke ediyor. Sonuçta aslında Paris anlaşmasında zorlayıcı bir mekanizma yoktur. Buna zorlanamaz Türkiye. Paris'i de onaylamayınca Türkiye hiçbir şey operasyonel hale gelemiyor.

11 Türkiye Birleşmiş Milletler İklim Değişikliği Çerçeve Sözleşmesỉni (BMİDÇS) 2004 yılında, Kyoto Protokolü’nü ise 2009 yllında onaylamıştır. Sözleşme’nin Ek - 1 listesinde yer aldığ 1 ve Protokol'ün Ek-B listesinde yer almadığı için zorunlu karbon piyasalarındaki esneklik mekanizmalarından faydalanamamaktadır. Türkiye, zorunlu piyasaların dışında oluşan, aynı zorunlu piyasalar gibi fakat bağımsız olarak işleyen gönüllü piyasalarda faaliyette bulunmaktadır 
Paris... Bu bir kolektif eylemdir. Siz bu uluslararası kolektif mekanizmanın parçası değilsiniz. Türkiye bunun ne kadar parçası olmak istiyor bu tartışmalı. Temel konu emisyon azaltımıdır. Emisyon azaltımı yapmadığınız sürece ne yaparsanız yapın... Emisyon azaltıyor musun? Emisyon artırıyor Türkiye...” (Ümit Şahin ile mülakat - 19.03.2019)

Paris Anlaşması, küresel ısınma ile mücadelede getirmiş olduğu yeni düzenlemeler ile Türkiye’nin özel koşullar söylemini ve bu doğrultudaki taleplerini de önemli ölçüde boşa çıkarmaktadır. Emisyon azaltımı noktasında gelişmiş ülkeler/gelişmekte olan ülkeler ayrımını geçersiz kılarak Kyoto Protokolünden farklı bir işletim sistemi getirmektedir. Türkiye’nin Paris Anlaşması’nı onaylamıyor oluşu bu anlaşmanın getirmiş olduğu yeni imkân ve araçlardan da mahrum kalmasına neden olabilecektir. Anlaşma ayrıca ülkelerin kendi ulusal tercih ve imkânları doğrultusunda anlaşmanın küresel ölçekte belirlemiş olduğu hedefe katkıda bulunmalarını öngörmektedir. Bu süreçte, ülkelerin bu doğrultudaki planları ve eylemlerinin önceki anlaşmalara göre çok daha sıkı ve sürekli bir biçimde denetlenmesi de öngörülmektedir. Türkiye'nin bu noktada da kurumsal kapasitesini geliştirmesi gerekmektedir (Mazlum, 2017). Özetle Paris Anlaşması uluslararası iklim müzakerelerinde yeni bir paradigmaya işaret etmekte ve farklı mekanizmaları beraberinde getirmektedir. Türkiye ise anlaşmayı onaylamayarak bu yeni düzenin dışında kalmaktadır. İşte bu yeni düzen içerinde Türkiye’nin özel koşullar söyleminin geçerliliği de sorgulanır hale gelmektedir.

Elbette, durum sadece “özel koşullar” söylemi çerçevesinde de ele alınamaz. Özel koşullar söylemi üzerinden yürütülen tavır ve siyaset üzerinden ulusal seviyede, çevre ve iklim değişikliği konularında var olan yerleşik bakış açısına da bir meşruluk ve süreklilik kazandırılmaktadır. Nitekim uluslararası müzakerelerdeki tutumun, iç siyasette son dönemde kendine alan açan hâkim milliyetçi söylemlerden ve kalkınmacı geleneğin tahakkümünden bağımsız düşünülmesi sağlıklı bir bakış açısı olmayacaktır.

İklim Değişikliği ve Hava Yönetimi Koordinasyon Kurulu (İDHYKK). 2011-2023 Ulusal İklim Değişikliği Eylem Planı, 2010-2023 İklim Değişikliği Stratejisi, 2011-2023 İklim Değişikliği Uyum Stratejisi ve Eylem Planlarına bakıldığında ise Türkiye’nin en azından kurumsal anlamda ve strateji geliştirme noktasında bir çaba içinde bulunduğu ifade edilebilir. Ancak, bu düzenlemelerin ortaya konması her ne kadar olumlu olarak nitelendirilebilirse de, Türkiye’nin sera gazı salımı artışlarına bakıldığında rakamlar ve istatistikler, Türkiye’nin bu alandaki kurumsal yapılanmasının etkinliği noktasında zafiyetlerin olduğuna işaret etmektedir. Bünyesinde birçok bakanlığı ve özel sektör temsilcilerini barındıran bu kurulun iklim değişikliği politikasındaki koordinasyon görevi hesaba katıldığında Türkiye’de devletin bu alanda bir sürekliliği sağlayamadığı gözlemlenmektedir. Türkiye’nin iklim değişikliği politikasında bu kurulun teknik açıdan etkin olması beklenir. Çünkü sözü geçen bütün eylem planları ve strateji belgelerinde, sorumlu bakanlık ve kamu kurumlarının ortaklaşa gerçekleştirmesi gereken görevler ve hedefler bulunmaktadır. Birbiriyle ortak hareket etmesi gereken sorumlu bütün kamu kurumları bu kurulun bünyesindedir. Son Ulusal Sera Gazı Emisyon Envanteri'nin ise yine aynı web sitesinde, 2012 tarihli olduğunu da işaret etmekte fayda görüyoruz. 
Türkiye'nin BMİDÇS Sekreterliği'ne sunduğu 3. İki Yıllık Rapor'da ${ }^{12}$ ise, 2030 yılı itibariyle mevcut politikalar senaryosunda en az \%21 emisyon azaltımı taahhüt etmiştir (1.174.780 ton yerine 928.987 ton sera gazı salımı öngörülmüştür). Bu hedef Türkiye’nin müzakereler kapsamında ortaya koymuş olduğu en güncel hedeftir. Burada da kastedilen sera gazı emisyonlarının tamamından \%21'lik bir azaltım değildir. Öngörülen düşüş, emisyonlardaki süregiden artışın içindeki nispi bir azaltımdır. 2015 yılında Türkiye’nin ilan etmiş olduğu Ulusal Katkı Belgesi ${ }^{13}$ de Türkiye'nin 2021-2030 dönemi kapsamında bu azaltım hedefini tutturmak için ortaya koyduğu strateji ve eylemleri içermektedir.

Bu verilerden de anlaşılacağı üzere Türkiye’de özellikle Kyoto Protokolü’nü takiben bazı adımlar atılmış olsa da somut, bağlayıcı hedeflerin net olarak ortaya konamadığını ve emisyon azaltımı noktasında bir iklim değişikliği politikasının oluşmadığını ifade edebiliriz.

“(...)Resmi belgelerde tanımlanmış bir iklim politikamız var evet. Ama uygulamaya baktığımızda bir iklim politikamız olmadığını rahatlıkla söyleyebiliriz. Birkaç nedeni var. Emisyon azaltmaya çalışmıyoruz biz. Çünkü ulusal belgelerde emisyon azaltmayı öngören bir hedef yoktur. Ulusal bağlayıcı hedef olur, uygulanır ve izlenir. Paris anlaşmasına taraf değiliz biz. İmzaladık anlaşmayı ancak onaylamadık. Meclis’e gelmedi daha. Bu onayı finansal mekanizmalara dâhil olmaya teknik destek almaya bu koşullara bağlamış olduğumuz için bu da en üst düzeyde siyasal iktidar tarafından açıklanmış olduğu için herhalde bu sorunun çözümü beklenecek onaylanması için. İklim politikasına geri dönersek, böyle bir azaltım politikamız yok. Ulusal iklim stratejisinde adaptasyon stratejisinde konulmuş bazı hedefler var onun dışında kalkınma planlarında bazı şeyler var önlemler var. Ama bunlar da sağlam bir iklim politikasının sonucu olarak değil de daha fazla su, tarım, ormancılık gibi sektörlerin kendisinin zaten gündeminde olan konular bağlamında yürüyor. İşte su tüketimini azaltmak hem tarımda hem evsel kullanımda, su kirliliğini önlemek, suyu daha verimli kullanmak falan gibi tarım ürünlerinde ürün desenini değiştirmek, tohum üretimi gibi çalışmalar yapılıyor” (Semra Cerit Mazlum ile mülakat - 26.02.2019)

“(...)Bir takım belgeler, planlar var ama onlar tamamen paperwork. Gerçek anlamda Türkiye’de bir iklim politikası yoktur.” (Ümit Şahin ile mülakat - 19.03.2019)

Uluslararası iklim rejimi ve taraf ülkeler arasında bir "koşulluluk" ve "bağlayıcılık" ilişkisi, örneğin $\mathrm{AB}$ entegrasyonu çerçevesinde $\mathrm{AB}$-Üye/Aday ülkeler arasında olduğu gibi, söz konusu değildir. Ancak, 1992'den günümüze uzanan müzakere süreci yine de bir müktesebat yaratabilmiştir. Taraf ülkeler yıllar içerisinde belirli öğrenme süreçlerinden geçmiş, yasal ve kurumsal düzenlemeler gerçekleştirmişlerdir. Emisyon azaltımına yönelik birçok mekanizma

12 https://www.iklimhaber.org/turkiye-3-iki-yillik-raporunu-bm-iklim-degisikligi-cerceve-sozlesmesisekretaryasina-sundu/ 
ve uygulama hayata geçirilmiştir. Türkiye’nin durumuna bakıldığında ise, tüm bu süreçlerden elde edinilen kazanımların yukarıda belirtilen nedenlerden ötürü çok sınırlı seviyede olduğu gözlemlenmektedir. Elbette, bu durumun ortaya çıkmasında ülkenin diğer bir takım önceliklerinin de belirleyici faktörler olduğunu ifade etmek gerekir. Enerji ve kalkınma politikaları bunların başında gelmektedir.

\section{Enerji Politikası, Cari Açık Sorunu ve Büyüme Stratejilerinin Kıskacında Gelişemeyen Bir Politika}

İklim değişikliğini bir kamu politikası olarak değerlendirmeye çalıştığımızda bu politikayı ilintili olduğu diğer sektörlerden özerk bir şekilde ele almak mümkün değildir. İklim değişikliği ile mücadele birden fazla kamu politikasının etkileşimini öngörmektedir. Sektörler arası bir uyum ve bütünlük olmadan bu alandaki mücadelenin etkin bir biçimde verilmesi söz konusu değildir. Ulusal seviyede ise iklim değişikliği sorunu ile ilgili alınabilecek tedbirlerin, önlemlerin ve geliştirilecek stratejilerin özellikle enerji ve kalkınma politikaları ile ilintili olduğu ifade edilebilir. Uluslararası iklim müzakerelerinin en temel hedefi mitigasyondur yani sera gazı emisyonlarında gerçekleştirilecek mutlak ve direkt azaltımlara yönelik politika ve uygulamaların taraf ülkeler tarafından hayata geçirilmesidir. Dünya genelinde ve Türkiye'de de emisyonlar en yüksek oranda enerji sektöründen kaynaklanmaktadır. Petrol, kömür ve benzeri fosil yakıtlara olan bağımlılığın azaltılması bu yöndeki en önemli hedeflerden biridir. Diğer yandan, ekonomik kalkınma politikalarında ve büyüme stratejilerinde karbon yoğun sektörlerden yüksek teknolojili, düşük karbonlu ve çevreye duyarlı bir üretim ve büyüme anlayışına geçiş önemsenmektedir. Dolayısıyla enerji ve kalkınma politikalarını ele almadan, bu alanlardaki uygulamalara bakmadan iklim değişikliği politikası ile ilgili çıkarımlar yapmak mümkün değildir.

Önceki bölümlerde sözünü ettiğimiz çevre politikalarındaki önceliklerin önüne geçen hâkim kalkınmacı anlayışın ve uluslararası müzakerelerdeki özel koşullar söyleminin de temel kaynakları Türkiye'deki kalkınma hedeflerinde, ekonomik büyüme stratejisinde ve enerji politikalarında gizlidir. Nitekim bu iç içe geçmişlik IDHYKK’nda, strateji ve eylem planlarında ve de uluslararası müzakerelerde Türkiye'yi temsil eden delegasyonun kompozisyonunda da gözlemlenmektedir. Bu delegasyonlarda, Çevre ve Şehircilik Bakanlığı, Ticaret Bakanlığı, Enerji ve Tabii Kaynaklar Bakanlı̆̆ı, Ekonomi Bakanlığı, Sanayi ve Teknoloji Bakanlığı, Orman ve Su İşleri Bakanlığı, Hazine ve Maliye Bakanlığı diğer bazı bakanlıklarla birlikte Türkiye’yi temsil eden kamu otoriteleri olarak yer almaktadır. Bunlar arasında, Çevre ve Şehircilik Bakanlığı ile Orman ve Su İşleri Bakanlığı’nın pozisyonu ve tavrı müzakerelerde daha olumlu ve yapıcı iken özellikle Enerji ve Tabii Kaynaklar Bakanlığı, Ekonomi Bakanlığı, Hazine ve Maliye Bakanlığı’nın tutumu daha savunmacı bir nitelikte bulunmaktadır.

“(...) Çevre ve Şehircilik Bakanlığı ile Enerji ve Tabii Kaynaklar Bakanlığı hem ulusal düzlemdeki kurumsal yapılarda hem de uluslararası müzakerelerde aynı platformlarda 
yer almaktadırlar. Bu ikisi genellikle çatışmaktadırlar." (Semra Cerit Mazlum ile mülakat - 26.02.2019)

Örneğin, Türkiye’nin Paris Anlaşması’nı onaylamamasındaki en önemli etkenlerden biri olarak da Enerji ve Tabii Kaynaklar Bakanlığı ile Hazine ve Maliye Bakanlıkları ön plana çıkmaktadırlar.

“(...) Çevre Bakanlığı daha ilerici bir pozisyona sahiptir öteden beri ancak pek bir imkânı yok hükümet politikası yüzünden. Enerji Bakanlığı burada muhafazakâr bir konumdadır tabii. Enerji Bakanlığı Kyoto’ya karşı çıkmıştı, Paris'in onaylanmamasını da onlar istiyor. Yerli kömürü kullanamayız eğer imzalarsak olay aslında bundan ibaret. Hazine ve Maliye de negatif bakıyor konuya. Cari açık meselesi, yenilenebilir enerjiyi de cari açığı artıran bir şey olarak görüyorlar. Bunun da maliyeti yüksek olduğu için buna karşılar. Gelen fotovoltaik paneller ileri teknoloji, bunlar için yine Çin’e falan para ödemek zorundayız, bunu istemiyorlar... İklim finansmanı vs. alalım ancak o zaman kabul edilebilir bu. Paris'in onaylanmasını durduran Hazine ve Maliye ile Enerji Bakanlığı'dır. Enerji Bakanlığı kömür nedeniyle, Hazine ve Maliye de cari açık ve finansman konuları sebebiyle karşı çıkıyor." (Ümit Şahin ile mülakat 19.03.2019)

Türkiye'nin enerji politikalarının son yıllardaki gelişimine baktığımızda, ekonomik büyüme beraberinde enerji tüketiminde de artışa neden olmuş ve bu durum Türkiye’nin enerji politikalarında çeşitlendirmeye gitme ihtiyacını ortaya çıkarmıştır. Yerli kaynaklardan üretilen enerji, artan talebi karşılamada yetersiz kalmış, sonunda Türkiye yaklaşık \%70 oranında ithal enerji kaynaklarına bağımlı hale gelmiştir. Artan ithal enerji faturası zaman içinde cari açı̆̆ın da artmasının en önemli nedeni olmuş, bu durum enerji ithalatının azaltılması yolunda yeni politikalar geliştirilmesini kaçınılmaz kılmıştır (SETA, 2017, s.18). Bu bağlamda 2016 verilerine bakıldığında da sera gazı emisyonlarının dağılımında enerji sektörü \%73, endüstriyel işlem ve ürünler \%13, tarım \%11, atık \%3 olarak ortaya çıkmaktadır. Enerji sektörü içerisinde de özellikle elektrik üretimi verileri önemlidir. TUİK 2014 Sera Gazı Envanterine göre de enerji sektörünün karbon salınımı, 1990 yılında 132,5 milyon ton (CO2 eşdeğerinde) iken 2014 yılında bu rakamın 340 milyon tona (CO2 eşdeğerinde) çıkmıştır. Diğer bir ifade ile 1990-2014 yılları arasında enerji sektörünün karbon salınımı \%156 artmıştır.

2017 yılında "Bağımsız Enerji Güçlü Türkiye” sloganıyla lanse edilen Milli Enerji ve Enerji Politikasının temel hedefi ise, enerjide dışa bağımlılığın azaltılması ve enerji ihtiyacını karşılamada kendi kendine yetebilen bir ülke haline gelmek olarak ifade edilmiştir. Bu doğrultuda arz güvenliği, yerlileştirme ve öngörülebilir piyasa eksenleri belirlenmiştir. Bakanlık, yerlileştirme konusunu söz konusu politikanın ikinci ekseni olarak ön plana çıkarmıştır. Özellikle yenilenebilir enerji yatırımları, nükleer santrallerin bir an önce ekonomiye kazandırılması, maden teknolojilerinin yerlileştirilmesi ve bunları yaparken yerli ekipman ve iş gücü kullanılması, politikanın yerlileştirme başlığının önemli amaçlarındandır (SETA, 2017:7). 
Milli Enerji ve Maden Politikasında yerlileştirme başlığı altında kömüre özel bir önem atfedilmektedir. Yerli kömür, Türkiye’de zaman içerisinde geri planda bırakılmış ve kurulu güç içerisindeki yerli kömür santrallerinin payı giderek azalmıştır. 2002 yılında yerli kömürün toplam kurulu güce \%22 oranında olan katkısı 2017 Mart ayı itibarıyla \%12,5 olarak gerçekleşmiştir. Önümüzdeki dönemde yerli kömür santralleri ile elektrik üretiminin artırılması noktasındaki projelerin geliştirilerek devam etmesi beklenmektedir. Bakanlık, 2015-2019 Stratejik Planı kapsamında 2019 yılına kadar yerli kömür kullanılarak yıllık 60 milyar kWh elektrik üretimi yapılması hedeflemiştir. Türkiye’de kömür rezervi son 10 yılda (2008-2018) \%50 artışla 17,3 milyar tona çıkarken, 4 bölgedeki 3,5 milyar tonluk rezerv de ekonomik değere dönüştürüleceği öngörülmüştür.

2016 verilerine göre yenilenebilir enerji toplam kurulu gücü 35 GW olan Türkiye, 2023 Hedefleri kapsamında elektrik üretiminin en az \%30'unu yenilenebilir enerji kaynaklarından karşılayabilmek adına bu alandaki çalışmalarına devam etmektedir. Kurulu gücün büyük kısmını hidroelektrik santraller oluştururken, rüzgâr ve güneş gibi modern yenilenebilir enerji kaynakları ile üretim yapma noktasında da önemli yatırımlar yapılmaktadır.

Şekil 1. Elektrik Üretimi ve Kurulu Güç / 2013 Verileri ve 2023 Hedefleri

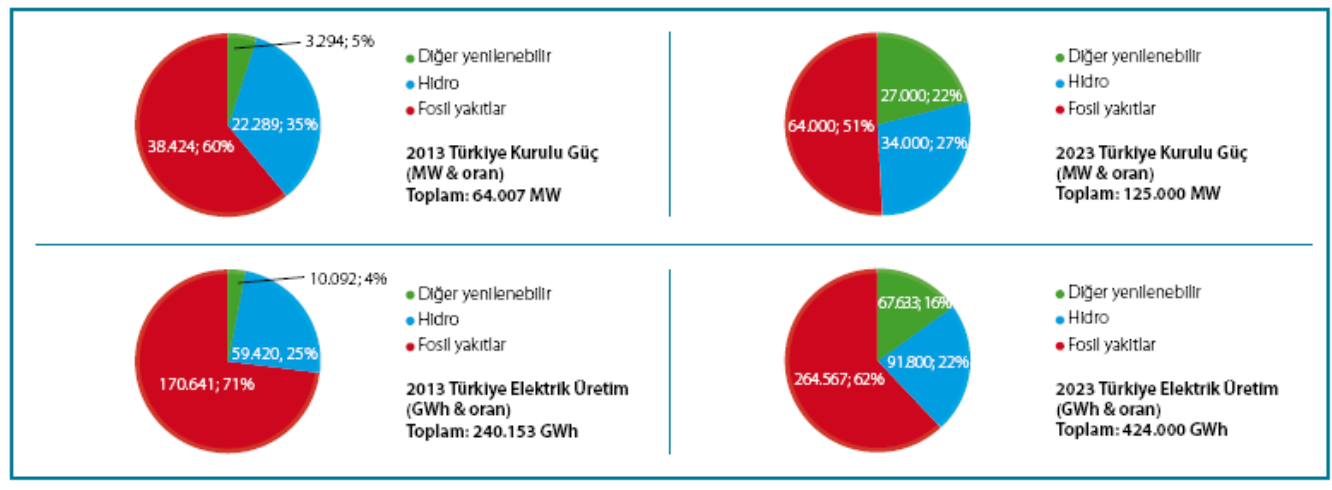

Kaynak: Türkiye Ulusal Yenilenebilir Enerji Eylem Planı, Aralık 2014, s.19

Şekilde de görüldüğü üzere, bir yandan yenilenebilir enerjinin kurulu güçteki payının artırılması hedeflenirken, diğer yandan fosil yakıtların oranı da artmaktadır. Her ikisi arasında bir kıyaslama yapıldığında elektrik üretiminde 2030 hedeflerine bakıldığında fosil yakıtlardaki artışın yenilenebilir enerji için öngörülen artıştan fazla olduğu göze çarpmaktadır. Bu durum da, emisyon azaltımı prensibi ile çelişmektedir.

"Şu anda enerji politikamız nedir? "Hepsi olsun”... Kömür olsun, güneş olsun, rüzgâr, HES hepsi olsun. Arza yönelik politika bu. Çeşitlendirme politikası emisyonu azaltmaz. Fosili kapatıp yerine yenilenebilir koyarsanız olur." (Ümit Şahin ile mülakat 19.03.2019) 
"Linyite yükleniyor Türkiye. Güneş rüzgâr enerjisinde de yatırımlar var. Kurulu güç 89gwt’a ulaşmış durumda. Türkiye’nin ihtiyacının çok üzerinde bir kurulu gücümüz var. Çünkü Türkiye’nin gelişmesi enerji tüketimi ve üretimi ile ölçülüyor. Çok klasik ve yerleşik bir gelişme tanımı yapıyoruz biz. Varını yoğunu enerjiye yatırıyor Türkiye son yıllarda. İşte kömür milli enerji politikasının önceliğidir. İklim politikası yok diyorum bundan dolayı yok. Evet işte çevre ile ilgili kurumlar çevre ile ilgili platformların içinde... İklim değişikliği koordinasyon kurulunda da, ulusal ve uluslararası müzakere süreçlerinde Enerji Bakanlığı da bulunuyor. Böyle bir iklim paketi var burada. Burada da bir enerji paketi var. İkisi birbiriyle ilişkilendirilmediği için bir iklim politikası yok diyorum. Bu ikisi çatışıyor. Bir yandan kömürü artırmaya çalışırken bir yandan da emisyonu azaltmaya niyetli olduğumuzu söylüyoruz. Kömür kullanımı artınca emisyonlarımız da arttı." (Semra Cerit Mazlum ile mülakat - 26.02.2019)

Enerji yatırımlarında yerli kömüre ağırlık verilmesinin en önemli nedeni olarak enerji ithalatından kaynaklanan cari açık problemi karşımıza çıkmaktadır. Bu noktada cari açık sorunu enerji politikasını yönlendirmekte, enerji üretiminde kömüre yönelim de iklim politikasının azaltım hedefiyle çelişmektedir.

“Enerji Bakanlığı'nın sitesine giderseniz, 4-5 ayaklı bir enerji politikası sayarlar ama bence tek ayağı var. Enerji kaynak ithalatını azaltmak... Bizim tek uygulamaya önem verdiği politika budur. En büyük kaynak ithalatı doğalgaz. Doğalgaz zaten jeopolitik olarak da sorunlu bir şey. Dışa bağımlı oluyorsunuz ama daha önemlisi cari açığınız artıyor. Doğalgazın yarattığı cari açığı nasıl kapatırız? En düşük maliyet ve teknoloji gerektiren ülkedeki kömürleri çıkarmak... Yurtdışından gelen kömürü azaltalım pek de azalmıyor. O zaman doğalgazı azaltalım onun yerine yerli kömürü koyalım... Politika bu olunca, bizim emisyonlarımız da artıyor doğal olarak. Bu da iklim değişikliği politikası oluşturmaya engel bir durum, aykırı bir durumdur." (Ümit Şahin ile mülakat 19.03.2019)

Azaltım hedefiyle çelişen bir diğer durum da, Türkiye’nin büyüme politikasında inşaat sektörünün son yıllarda giderek en çok ağırlık verilen sektör haline gelmesidir.

“(...) Ana ekonomik büyüme rotasının inşaat sektörü ve karbon yoğun olması yani inşaat ve bunun yan bileşenleri, beton, çimento, alüminyum, benzin, demir-çelik... Bunlara bakarsanız, bunların hepsi enerji-yoğun bileşenler, alanlar. İnşaat dediğiniz sektör baştan aşağıya enerji yoğun ve hafriyata dayalı, kazmaya dayalı bir ekonomi modeli son dönemde benimsenen... Yüksek teknolojili bir model değil bu. İklim değişikliği politikası... Al Gore gibi bir vizyonunuz olması lazım. Yeşil kapitalizm... Az karbonlu yüksek teknolojiye dayalı bir model oluyor bu.” (Ümit Şahin ile mülakat - 19.03.2019)

İnşaat sektörü dendiğinde sorun bunun sadece karbon-yoğun bir sektör olması ile sinırlı kalmamaktadır. Demir-çelik gibi yan sektörleri de inşaat sektörü ile birlikte düşünmek gerekir. 
İnşaat sektörü aynı zamanda, Çevre ve Şehircilik Bakanlığı’nın "Şehircilik" ayağının daha fazla ön plana çıkmasını, öncelik kazanmasını beraberinde getirmektedir. Çevre ve iklim değişikliği ile ilgili en önemli rolü oynaması gereken bakanlığın, kentsel dönüşüm, imar ve rant gibi konularda kilit pozisyonda yer alması, dolayısıyla sermaye birikim sürecinde büyük öneme sahip inşaat sektörünün önceliklerine yoğunlaşması da kendi içinde çelişkili bir durumu doğurmaktadır. Sonuç olarak, iklim değişikliği politikasının devletin öncelikleri sıralamasında henüz kendine üst sıralarda bir konum elde edemediğini ifade edebiliriz.

“Türkiyede iklim değişikliği politikası ve diğer yerleşik kamu politikaları arasında sağlıklı bir ilişki kurulamıyor Yerleşik diğer kamu politikaları kendi hatlarından ilerledikleri sürece iklim çok fazla ön plana çıkmıyor çünkü. İzole kalıyor. Bunlarla bağlantı kurulamıyor iklim politikası arasında." (Semra Cerit Mazlum ile mülakat - 26.02.2019)

İklim değişikliği politikasının ana hedefi olan azaltımda etkinliğin sağlanması için emisyonların önemli kısmını doğuran sektörler ile entegrasyonunun sağlanması, bu bağlamda bu sektörlerin de iklim değişikliğine duyarlı olacak şekilde yeniden ele alınması gerekmektedir. Türkiye ise aksi bir durumun söz konusu olduğu ileri sürülebilir.

\section{5. İklim Değişikliği Politikasında Merkeziyetçiliğin Gölgesinde Yerel Yönetimler}

Toplumsal, ekonomik ve ekolojik sonuçlarıyla bir sürdürülebilir kalkınma sorunu olan küresel iklim değişikliği yerel yönetimlerin gündeminde de önemli bir yer tutmaktadır. İklim değişikliği ile mücadele dünyada yerel yönetim politikalarının ve yerel kalkınma çabalarının parçası haline gelmiştir. Gelişmiş ve gelişmekte olan ülkelerde yerel yönetimler hem sera gazlarının azaltılması hem de iklim değişikliğinin etkilerine uyum amaçlı politika ve programlar uygulamaya başlamıştır. Bazı ülkelerde yerel yönetimler merkezi yönetimlerce zorunlu kılınmakta ve özel programlarla desteklenmektedir. Bu anlamda, iklim değişikliğine dönük önlemlerin çağdaş yerel yönetim hizmetleri arasına girdiği kabul edilmektedir (Mazlum, 2009).

Dolayısıyla, iklim değişikliği sorunu ile mücadelede ulus üstü ve ulusal yönetim kademelerinin yanında yerel yönetim kademelerinin de ayrı bir önemi ve fonksiyonu vardır. Çalışmanın önceki iki bölümünde uluslararası müzakereler ve ulusal kamu politikaları ile ilişkisi çerçevesinde Türkiyede iklim değişikliği politikasının konumunu ve durumunu açıklamaya çalıştık. $\mathrm{Bu}$ bölümde, iklim değişikliği politikasındaki yerel yönetim boyutunu irdeleyeceğiz.

İklim değişikliği ile mücadelede kentlerin ve yerel yönetimlerin uygulamalarından hareketle aşağıdan yukarı bir yaklaşımın ön plana çımaya başlaması da söz konusudur. Bu bağlamda iklim değişikliği politikası söz konusu olduğunda bir ülkedeki merkezi yönetim ve yerinden yönetim ilişkileri, idari yapının örgütlenme biçimi (merkeziyetçi mi, adem-i merkeziyetçi mi?) ve yönetim zihniyeti ile yerel yönetimlerin teknik-idari ve öğrenme kapasiteleri, kent ağbağları ile olan bağlantıları ve uluslararası oluşumlarla olan ilişkileri incelenmesi gereken konulardır. 
Yerel yönetimler, iklim değişikliği ile mücadelede enerji verimliliği, ulaşım, atıklar, kent planlaması ve kentsel dönüşüm gibi alanlarda stratejiler geliştirmekte ve uygulamaları hayata geçirebilmektedirler. Yerel yönetimler kendi aralarında (diğer yerel yönetimler veya uluslararası ortaklar ile) işbirlikleri kurabilmekte diğer yandan uluslararası oluşumlara üye olarak hem bu alanda kendilerine meşruiyet kazandırmaktadırlar hem de bunların sağladığı finansal ve lojistik desteklerden faydalanabilmektedirler. Bunlardan bazıları Uluslararası Sürdürülebilir Kentler Birliği (ICLEI) - İklim Dostu Kentler Kampanyası, Avrupa Belediye Başkanları Sözleşmesi (Başkanlar Sözleşmesi). Büyük Kentler İklim Liderlik Grubu (C40). Dünya Belediye Başkanları İklim Değişikliği Birliği gibi oluşumlardır. Yerel yönetimler ayrıca Avrupa Birliği (IKLIM IN, Making City vb.). Dünya Bankası ve Birleşmiş Milletler Kalkınma Programı’nın sağladığı finansal imkânlardan yararlanarak da projeler vasıtasıyla uygulamaları hayata geçirebilmektedir. Türkiye’den de bazı belediyeler ICLEI ve Başkanlar Sözleşmesi’ne dâhil olmuşlardır.

Bu bölümde değerlendirmeye alacağımız Kadıköy Belediyesi de hem ICLEI’ye hem de Başkanları Sözleşmesi’ne katılmıştır. Kadıköy Belediyesi 2010-2014 Stratejik Planı’nda Kadıköy’de üretilen sera gazı salımlarının azaltılmasıyla ilgili hedefler koymuştur. Kadıköy Belediyesi, Kurumsal Sera Gazı Emisyonlarının Hesaplanması Projesini hayata geçirmiştir. Kadıköy’de, Avrupa Belediye Başkanları Sözleşmesi kapsamında Sürdürülebilir Enerji Eylem Planı ve İklim Eylem Adaptasyon Planı da hazırlanmıştır Kadıköy Belediyesi’nin farklı yönetişim tarzlarını kullanarak geliştirdiği iklim projeleri (belediyenin kendi faaliyetlerini yönetmesi, enerji verimliliği ve yenilenebilir enerji projeleri, toplu taşıma vb.) mevcuttur.

Türkiye'de merkezi idare hazırladığ iklim değişikliği ile ilgili resmi plan ve belgelerde yerel yönetimlerin önemini vurgulamaktadır. Türkiye İklim Değişikliği 5. Bildirimi, yerel yönetimleri iklim değişikliği politikasının kilit paydaşlarından biri olarak nitelemektedir (T.C. Çevre ve Şehircilik Bakanlığı, 2013: 12, 102). Türkiye Cumhuriyeti Ulusal İklim Değişikliği Eylem Planı 2011-2023 (İDEP). bazı iklim eylemlerinin uygulanmasında yerel yönetimleri "sorumlu kurum/ kuruluş”, bazı eylemlerde ise "ilgili kurum/kuruluş” olarak tanımlamış ve kendi yerel iklim eylem planı hazırlamalarının önemli olduğunu belirtmiştir (T.C. Çevre ve Şehircilik Bakanlığı, 2011: 1-2). Keza, Türkiye’nin İklim Değişikliği Stratejisi ve Uyum Planı 2011-2013, uyum stratejilerinde yerel yönetimleri ilgili kuruluş olarak nitelemiş ve yerleşim yerlerini etkileyecek afetler için bütünleşik afet tehlike haritalarının hazırlanmasına yönelik kılavuz hazırlanmasını gerekli görmüştür (T.C. Çevre ve Şehircilik Bakanlığı, 2012: 49).

Merkezi idarenin iklim değişikliği politikaları ile ilgili hazırladığı planlar ve belgeler (İDEP, 2011-2023,Türkiye’nin İklim Değişikliği Stratejisi ve Uyum Planı 2011-2023 vb.). belediyeleri yerel azaltım ve uyum tedbirleri alma doğrultusunda yönlendirmektedir. Örneğin Bütünleşik Kentsel Gelişme Stratejisi ve Eylem Planı 2010-2023 (KENTGES). iklim değişikliği, mekânsal planlama, ulaşım, altyapı, enerji verimliliği, yenilenebilir enerji gibi konularda stratejiler içermektedir. KENTGES belgesinde iklim değişikliği azaltım ve uyum tedbirleri de yer almaktadır: "Yerleşmelerde iklim değişikliğine yönelik uyum ve azaltım stratejileri geliştirilecek, planlama ve yapılaşmaya yönelik usul ve esaslar belirlenecektir” (Demirci, 2015, s. 90) 
Gaziantep, Bursa, Konya Büyükşehir Belediyeleri, Kadıköy, Bornova, Seferihisar, Karşıyaka ve Kartal gibi ilçe belediyeleri Türkiyede iklim değişikliği politikalarını uygulamaya çalışan öncü belediyeler olarak ön plana çıkmaktadır. Bu bölümde incelemeye dâhil edilen Kadıköy Belediyesi de bu öncü belediyeler arasındadır ve iklim değişikliği ile mücadelede edinmiş olduğu tecrübe ve birikim ülkedeki diğer belediyelere de örnek teşkil etmektedir. Verilen örneklerin sayısı Türkiye geneli hesaba katıldığında kısıtlıdır (Orhan, 2014, s.130). Dolayısıyla, Türkiye’de tüm ülke çapında iklim değişikliği ile ilgili standart yerel iklim değişikliği politikası ve uygulamalarından söz etmek mümkün değildir. Merkezi yönetim kurumlarının çeşitli plan ve stratejilerde yerel yönetimlere bir takım görev ve sorumluluklar yüklemesi söz konusudur ancak bunların uygulamaya yansımadığ 1 ve kâğıt üstünde kaldığg gözlemlenmektedir.

Genel olarak bakıldığında Türkiyede yerel yönetimlerin eylemleri, doğrudan düzenleme yapma, doğrudan hizmet sağlama yolu ile azaltım tedbirleri almak yerine rol model olarak kendi faaliyetlerine yoğunlaşma ve özel sektöre vb. imkân vererek azaltım tedbirlerini kolaylaştırma olarak biçimlenmektedir (Demirci, 2015, s.83). Ayrıca, belediyeler kent ya da belediye sınırları dâhilinde sürdürülen bütün faaliyetlerden kaynaklanan sera gazı emisyonlarının azaltılmasından ziyade belediye faaliyetlerinden kaynaklanan emisyonların azaltılmasına odaklanmaktadırlar. Diğer yandan, bu konu ile çalışan belediyelerinin sayılarının azlığı iklim değişikliği politikasının yerelde stratejik şehircilik bağlamında değil daha çok gönüllü belediyecilik seviyesinde ele alındığını kanıtlar niteliktedir. Belediyelerin iklim değişikliğini diğer bütün hizmetleri ve faaliyetleri kapsayacak bir yerel gündem maddesi olarak görmeleri ve stratejik planlarını buna göre oluşturmaları Türkiye’de halen söz konusu değildir. Bunu gerektiren bağlayıcı bir yasal mevzuat da ortada yoktur. Türkiyede birçok belediyenin iklim değişikliği ile ilgili hiçbir planı, stratejisi ve eylemi de bulunmamaktadır.

Burada esas dikkat çekilmesi gereken noktalardan biri de, hâlihazırdaki "öncü" veya örnek belediyelerinin uygulamalarının da merkeziyetçi yönetim ve planlama pratikleri ile fazlasıyla sinırlandırlıyor hatta engelleniyor olmasıdır. Türkiye'deki siyasal iktidar, ilk iktidar döneminde yerelleşme yönünde önemli adımlar atmaya çalışmıştır (Büyükşehir Belediye, Belediye ve İl Özel İdareleri Yasaları, Kalkınma Ajansları bunlar arasındadır). Aşırı merkeziyetçi yönetim yapısı ve zihniyetinin gevşetilmesi ve yerel yönetimlerin kendi görev ve yetki alanlarında idari ve mali özerkliklerinin güçlendirilmesi noktasında bu adımlar olumlu sonuçlar doğurmuştur. Ancak 2012'de çıkarılan Büyükşehir Belediye Yasası'nı takip eden süreçte bu atılan olumlu adımlardan geriye dönüş başlamıştır. 2017 yılında kabul edilen Cumhurbaşkanlığı Hükümet Sistemi ile beraber de yönetim yapısı ve zihniyetinin tekrardan güçlü bir biçimde merkeziyetçiliğe doğru kaymaya başladığı gözlemlenmektedir. Giderek artan bu merkeziyetçi eğilimin yansımalarını iklim değişikliği politikasında ve devamında yerel yönetimlerin bu alanda yaşadıkları problemlerde de gözlemlemek mümkündür. Merkezi yönetim iklim değişikliği politikası kapsamında bir yandan yerel yönetimlere yönelik somut yasal, yapısal ve mali düzenlemeleri hayata geçirmemekte, diğer yandan da yerel yönetimlerin iklim değişikliği ile ilgili yaptığı veya yapabileceği düzenlemeler ve uygulamalarla çelişecek şekilde tepeden inme müdahaleler ve kararlarla yerel yönetimlerin kapasitesini ve hareket alanlarını da sınırlandırmaktadır. 
“(...)Zaten bakanlığın bu konuda koordinasyon görevi var. Yetki ve sorumluluklar noktasında da yönetim kademeleri arasında bir çakışma bir çatışma var gibi görünüyor evet. Ulusal iklim planında hem yerel yönetimlerin destekleneceği söyleniyor ama bu alanda merkez somut hiçbir şey yapmiyor. Merkez desteklemediği gibi bazen köstek de oluyor bizim çabalarımıza." (Ali Tulumen / Kadıköy Belediyesi Çevre Koruma ve Kontrol Müdürlüğü ile mülakat - 15.04.2019)

Çevre Düzeni Planlarının hazırlanması Çevre ve Şehircilik Bakanlığı’nın yetkisindedir. Ancak belediyeler, arazi kullanım kararları, ulaşım, konut ve imar planları gibi önemli enstrümanları kullanarak aslında önemli bir emisyon azaltım potansiyeline de sahiplerdir. Buna karşın, bu enstrümanların etki alanındaki konulara merkezi kurum ve kuruluşların yukarıdan aşağıya ve dayatmacı bir şekilde müdahil olmaları bu olasılığı engellemektedirler.

“(...)Şöyle açıklayayım. Örneğin Kadıköy’e bu Kanal İstanbul Projesinden dolayı Bostancı kısmına yaklaşık 110 hektarlık bir dolgu alanı ve onun da tam karşısına bir tane 123 hektarlık bir ada yapılması projelendiriliyor. Ancak bununla ilgili belediyemize hiç görüşü sorulmuyor. Oysaki bizim sınırlarımız içinde bunlar. Yine Fenerbahçe'de marina bölgesindeki marina alanının iki kat daha artırılması için ihaleye çıkılıyor ama Kadıköy belediyesine danışılmıyor. Benzer bir örnek daha vereyim. Rıhtımda bir ön arıtma tesisi var onun yanına biyolojik arıtma için ayrılmış olan alana cami projesi yapılıyor ama bununla ilgili olarak yine belediyenin görüşü sorulmuyor. Sormayanlar? Merkezi yönetime bağlı olan yetkili birimler sormuyor. Bazılarında Çevre ve Şehircilik Bakanlığı bazılarında Ulaştırma Bakanlığı bazılarında Büyükşehir Belediyesi... Peki, ne oluyor? Kadıköy Belediyesi mahkeme kararıyla marina bölgesindeki projeyi durdurdu. Yine Haydarpaşa Garı ve çevresinin ticari alanlara açılmasının önüne mahkeme yargı süreçleriyle önüne geçildi. Buna benzer mücadeleler bu şekilde veriliyor. Yani bunun gibi birçok konuda belediyeye danışılmıyor onayı istenmiyor. Bütün bu müdahaleler ve alınan kararlar sonucu elbette çevre de olumsuz etkileniyor" (Ali Tulumen / Kadıköy Belediyesi Çevre Koruma ve Kontrol Müdürlügü ile mülakat 15.04.2019)

“(...)Sanayi arazi kullanım alanlarına ilişkin yetkilerimiz işletilemiyor. Bırakalım yetkili kurum olmayı bize danışılmıyor bile. O zaman yapabildiklerimiz de kendi dar çerçevemizle sınırlı kalıyor. O halde kapsamlı bir azaltım hedefini tutturmak pek de mümkün görünmüyor. Bu konulara müdahale edebilseydik belki yüzde 20 değil yüzde 40 gibi bir emisyon azaltımı gerçekleştirebilirdik. Yine azaltım yapabileceğiniz kalemlerde daha çok çalışarak yüzde 20 hedefimize ulaşmaya çalışıyoruz." (Ali Tulumen / Kadıköy Belediyesi Çevre Koruma ve Kontrol Müdürlüğü ile mülakat - 15.04.2019)

Kentsel Dönüşüm politikası da aslında ilk etapta yerel yönetimleri ilgilendiren bir konu olmakla birlikte merkezi yönetimin yerel yönetimleri bununla ilgili karar süreçlerine dâhil etmesi genellikle söz konusu olmamaktadır. Merkezi yönetimin kentsel dönüşüm ile ilgili kararların alınması 
süreçlerinde ve uygulamada yukarıda sözü edilen resmi belge ve stratejilerde öngörüldüğü gibi yerel yönetimler ile etkin bir koordinasyon halinde olamadığı ifade edilebilir.

\begin{abstract}
"Yönetim kademeleri arasında ne yasal ne de yapısal anlamda ne de uygulamada bir koordinasyon sağlanmış değildir. Kentsel dönüşüm alanında kurulan 11 tane beton santrali var. Burada bize sorulmuyor. Koordinasyon bu açıdan bakıldığında bulunmuyor. Mesela bu santral kurma konusu bizim bilgimiz dâhilinde olmadı. Bu otomatikman sanayideki enerji tüketimini de artırıyor ve bizim hedeflerimizin sapmasına da neden olabiliyor." (Ali Tulumen / Kadıköy Belediyesi Çevre Koruma ve Kontrol Müdürlüğü ile mülakat 15.04.2019)
\end{abstract}

"Fikirtepe kentsel dönüşüm bölgesi vardı. O bölgeye Kadıköy Belediyesi’nin hiçbir izni ve bilgisi olmadan on bir tane beton santrali kuruldu. Bu santrallerden kaynaklanan hava kirliliğinden dolayı Kadıköy’de çok büyük sıkıntılar yaşandı. Bu kararı veren Çevre ve Şehircilik bakanlığıdır." (Ali Tulumen / Kadıköy Belediyesi Çevre Koruma ve Kontrol Müdürlüğü ile mülakat - 15.04.2019)

Tüm bu verilerin ışığında, Türkiye’nin iklim değişikliği politikasında emisyon azaltımı noktasında tıpkı ulusal diğer politikalarda (enerji, kalkınma) olduğu gibi yerel yönetimler düzeyinde de kapsayıcı, bütünleşik ve somut hedef ve uygulamaların ortaya konamadığı gözlemlenmektedir. Oysa dünyada kentlerin ve yerel yönetimlerin hem azaltım hem de uyum politikaları çerçevesinde ulusal hükümetlerinin desteğiyle (-bir diğer ifadeyle güçlü bir merkez-yerel koordinasyonu ve işbirliğiyle). veya onlardan özerk bir şekilde kendi yetki ve imkânlarıyla ciddi ilerlemeler kaydettikleri bilinmektedir. Türkiye'de, merkeziyetçi yönetim yapısı ve zihniyetinin sonucu olarak yerel ölçekte gerçekleşebilecek olumlu politika ve uygulamaların da önüne set çekilmektedir. İklim değişikliği politikası dendiğinde akla gelen ilk yetkili merkezi yönetim birimi olan Çevre ve Şehircilik Bakanlı̆̆ı̀nın "yerel” ile olan ilişkisi de bu anlamda manidardır. Bakanlık, kentsel dönüşüm, altyapı ve planlama gibi birçok konuda "çevreden" taraf olmak yerine merkezin siyasal ve ekonomik öncelikleri doğrultusunda hareket etmektedir. Buna ilave olarak, Ulaştırma Bakanlığı ve Enerji ve Tabii Kaynaklar Bakanlığı gibi bakanlıklar da, kentlerin görev ve yetki alanlarına giren ve çevreye ilişkin yaşamsal öneme sahip konularda kararları, sermaye birikimi süreci ve büyüme politikalarını kayıracak şekilde kentlerdeki mahalli idareleri kale almadan uygulamaya geçirebilmektedirler. İstanbuldaki Yavuz Sultan Selim Köprüsü veya Üçüncü Havalimanı ile ilgili alınmış olan kararlarda İBB’nin merkezi yönetime oranla etkisiz kalması veya etkisiz "kılınması" örneği de bu doğrultuda verilebilecek güçlü örneklerden biridir. Dolayısıyla Türkiyede yerel yönetimlerin iklim değişikliği ile ilgili çalışmaları ve uygulamaları kendi bünyelerinde gerçekleştirebildikleri sınırlı azaltım hedefleriyle, atık alanındaki faaliyetleriyle ve uluslararası kurum ve kuruluşların sağladığı imkânlardan yararlanarak hayata geçirebildikleri projelerle sinırlı kalmaktadır. 


\section{Değerlendirme ve Sonuç}

Hassenteufel'e göre, kamu politikaları analizi üç temel soru üzerine kuruludur. İlk soru, kamu politikalarının neden ve ne için hayata geçirildiklerine dolayısıyla kamu politikasının kökenlerine göndermede bulunur (hedefler ve politikanın varlık nedenleri). İkinci soru, kamu politikası ile ilgili olan aktörlerin nasıl hareket ettiklerine odaklanır. Burada, politikanın uygulama araçları ön plana çıkar, çünkü politika aktörleri bu araçları kullanarak hedeflerine ulaşmaya çalışırlar. Üçüncü olarak ise hedef kitle yani kamu politikasının etki etmeyi öngördüğü toplumsal kesimler ön plana çıkar (Hassenteufel, 2008, s.8). Ayrıca, bir kamu politikası incelenirken, o kamu politikasının kesiştiği veya ilintili olduğu diğer kamu politikaları ve sektörlerin etkileri de hesaba katılmalıdır. Birbiriyle dolaylı ya da dolaysız olarak ilintili olan kamu politikaları etkileşim halindedirler ve kamu otoriteleri tercihen bu sektörlerden bazılarının önceliklerini diğerlerinin önüne koyabilmektedir (Hassenteufel, 2008, s. 122).

Kamu politikaları analizine ilişkin yukarıdaki ifadelerden hareketle Türkiye’nin iklim değişikliği politikasına ilişkin bir takım çıkarsamalar ve değerlendirmeler yapmak mümkündür. Türkiyede devletin iklim değişikliği ile mücadele noktasında temel muhatabı olarak BM çatısı altındaki uluslararası iklim rejimi karşımıza çıkmaktadır. Burada altı çizilmek istenen nokta, Türkiye’nin iklim değişikliği sorununu bir dış politika konusu olarak görmeye devam etmesidir. Dolayısıyla iklim değişikliği sorununun ulusal düzlemde içselleştirilemediğini ifade etmek mümkündür. Devletin bu politika alanındaki temel motivasyonu uluslararası müzakerelerdeki çıkarlarına odaklanmış durumdadır. Ülkenin her yerinde giderek etkisini artıran iklim değişikliği sorunları ile birebir muhatap olan yerel, bölgesel ve sektörel aktörler ile toplumsal kesimlerin bu yöndeki talep ve ihtiyaçlarının politika sürecine dâhil edilmeleri yönünde ilerlemeler kaydedilememiştir. Buradan hareketle, Türkiye’deki iklim değişikliği politikasının kurumsal yapılanmasına ve temel hedeflere bakıldığında devletin ve devletin iktisadi hedefleri ile çıkarları örtüşen sermaye aktörlerinin ön planda olduğu gözlemlenmektedir. Küresel ısınma ile mücadele kapsamında ve sürdürülebilir kalkınma çerçevesinde gerçekleşmesi gereken maliyet artırıcı önlemlere ve bu yöndeki değişimlere karşı devlet ve özel sektörün bir çıkar ve söylem birlikteliği içinde olduğu ortaya çıkmaktadır. Tam da bu noktada, hazırlanan ulusal planlar ve yasal mevzuat ile bunları uygulayacak ve takip edecek kurumsal yapılanmanın da etkinliği ve verimliliği sorgulanır hale gelmektedir. Bu plan ve strateji belgelerinde sıklıkla altını çizdiğimiz üzere nispi azaltımların ötesinde somut emisyon azaltım hedefleri belirlenmemiştir. Var olan üretim altyapısı, enerji sektörü ve ilgili sektörlerde öngörülen uyum tedbirleri dışında bu belgelerden hareketle bir iklim değişikliği politikasının varlığından söz etmek olası değildir. Böylesine bir politikanın finansal/ yapısal düzenlemeleri de gereken seviyede kurgulanmış değildir. Buradan hareketle, devletin büyüme stratejileri ve ekonomik hedeflerini gerçekleştirme önceliklerinin karşısında iklim değişikliğine yönelik tedbirler ve öngörüler ikincil önemde kalmaktadır. İklim değişikliği ve çevre politikalarını içeren bütünleşmiş ve sürdürülebilir bir ekonomik kalkınma anlayışından uzak kalınmıştır. Belirtilen devlet-sermaye birlikteliğinin benimsemiş olduğu hedefler, söylem ve değerler sistemi çerçevesinde tanımlanan iklim değişikliği politikasının diğer paydaşlar ve toplumsal aktörler ile olan bağıntıları kurgulanamamıştır. Benzer bir yönetişim zafiyeti, 
merkezi yönetim ve yerel yönetimler arasında da söz konusudur. Merkezi yönetim ve yerel yönetimler arasında bu alanda kurumsal koordinasyon yeterli seviyede sağlanamamıştır. Ayrıca ülke genelinde belediyelerin sadece bazılarının bu alanda kendi girişimleriyle çalışmalar içinde bulundukları ancak bunların da izole bir biçimde hem yerel hem de merkezi diğer aktör ve kurumlarla sağlıklı bir etkileşim halinde hareket edemedikleri ortaya çıkmaktadır.

Bu çalışmada kamu politikaları analizi perspektifinden Türkiye’nin iklim değişikliğipolitikasındaki kısıtlılıkları ve sorunları dört başlık altında incelemeye çalıştık. İklim değişikliğini politikasını konuyla ilgili resmi belgelere ve kurumsal örgütlere indirgemeden bu politikayı kuşatan farklı faktörleri ve bağlamları ele alarak tartışmayı amaçladık. Ulus-üstü dinamikten başlayıp yerel yönetim ölçeğine uzanarak iklim değişikliği politikasında rol alan farklı yönetim kademelerinde gözlemlenen söylemler, pozisyonlar ve uygulamalar özelinde bir takım değerlendirmelerde bulunduk. Diğer yandan, iklim değişikliği politikasında belirleyici olan diğer sektör ve politikaları da ele alarak yatay biçimde kamu politikalarının birbirlerini etkileme süreçlerine eğilmeye çalıştık. Çalışma önermiş olduğu bu çok boyutlu yaklaşım ile kendisini takip edecek diğer araştırmalar için perspektifler sunmaya gayret etmiştir. Her bir başlık altında genel değerlendirilmelerde bulunulan konularda, tekil araştırmalara gidilebileceği gibi bunlar arasındaki etkileşimlere odaklanacak daha detaylı analizlerin yapılabilmesi de söz konusu olabilir. Bununla birlikte çalı̧̧mada bir takım kısıtlılıklar da mevcuttur. Bu alanda Türkiye özelinde çalışmayı sürdürecek olan araştırmacılar için iklim değişikliği politikasında var olan belirleyici aktörler (TBMMilgili komisyon üyeleri, siyasi parti yetkilileri, bakanlıklar düzeyinde teknokratlar ve uluslararası müzakerelerde bulunan yetkililer, çevre ve iklim değişikliği ile ilgili faaliyet gösteren sivil toplum kuruluşlarının temsilcileri, özel sektör temsilcileri vb.) ile gerçekleştirilecek sözlü mülakatlar sayesinde, Türkiye’nin iklim değişikliği politikasının çeşitli evrelerine (politika oluşturma, karar alma ve uygulama süreçleri) daha geniş bir biçimde ışı tutulabilecektir. Türkiye ile benzer sosyoekonomik gelişmişlik seviyesinde bulunan diğer ülkeler ile Türkiye arasında söylemler, aktörler, uygulama araçları ve kurumsal yapılanma gibi parametreler dikkate alınarak karşılaştırmalı analizler hem ulusal hem yerel politikalar çerçevesinde yapılabilir.

\section{Kaynakça}

Aykut, C. Dahan, A. (2014). Gouverner le climat?: Vingt ans de négociations internationales, Paris: Presses de Sciences Po

Baykan, B. (2008). “Türkiye'de Çevre: Sorunlar, Aktörler ve Yeni Alanlar”, (Araştırma Notu). Bahçeşehir Üniversitesi, Betam 08.05.2008

Baykan, B. (2013). “Türkiye’de iklim hareketinin kısa tarihi: Uluslararası müzakerelerden, ulusal politikaya”, (Araştırma Notu). Bahçeşehir Üniversitesi, Betam, 18.04.2013

Boussaget L., Jacquot, S., Ravinet, P. (2014). Dictionnaire des politiques publiques, Sciences Po Les Presses, Paris

Cerit Mazlum, S. (2009). "Küresel İklim Değişikliğine Karşı Yerel Çözümler: Yerel İklim Politikalarının Karşılaştırmalı İncelemesi”, Bilgin, Akay, Ertan (ed) Ulusal Yerel Yönetimler Sempozyum Bildirileri Ulusal Kalkınma ve Yerel Yönetimler - 2-, 1009-1025 
Cerit Mazlum, S. (2017). “Turkey And Post-Paris Climate Change Politics: Still Playing Alone”, New Perspectives On Turkey, Cambridge University Press, cilt:56, 145-152. doi: 10.1017/npt.2017.20

Demirci, M. (2015). “Kentsel İklim Değişikliği Yönetişimi”, Erciyes Üniversitesi İktisadi ve İdari Bilimler Fakültesi Dergisi, Temmuz-Aralık 2015, 46: 75-100

Duru, B. (2013). “Türkiye’de Yeşiller Hareketinin Sürdürülebilirliğì, Perspectives, S.3, s. 4-7

Fischer, F., Miller, G., Sidney, M. (2007). Handbook of Public Policy Analysis, Theory, Politics and Methods, CRC Press, Taylor and Francis Group

Giddens, A., "The politics of climate change”, www.policy-network.net, September 2008

Hajer, M. (1993). "Discourse Coalition and Institutonalization of Practice: The Case of Acid Rain in Britain" Fischer F., Forester J. (ed) The Argumentative Turn in Policy Analysis and Planning Duke University Press Durham and London, 1993, 43-76

Hassenteufel P. (2008). Sociologie politique : Laction publique, Armand Colin, Paris

Kaya, Y. (2012). Uluslararası Çevre Antlaşmalarına Uyum Sorunu, Bursa: Ezgi Kitabevi.

Kaypak, Ş. (2011). Küreselleşme Sürecinde Sürdürülebilir Bir Kalkınma İçin Sürdürülebilir Bir Çevre, KMÜ Sosyal ve Ekonomi k Araştırmalar Dergisi, 13/20, 19-33.

Keskin, T. “İklim Değişikliği ve Enerji Sektörü”, Mühendis ve Makina, Cilt:52, 617: 63-69

Kübler D., De Maillard J. (2009). Analyser les politiques publiques, Presses universitaires de Grenoble,

Muller P. (2006). Les politiques publiques, Paris, Que sais-je, 6ème édition

Orhan, G. (2014). Türkiye’de Yerel Yönetimler ve Çevre: Küresel Sorunlar, Yerel Çözümler ve Yeniden Merkezileşme Tartışmaları, Ezgi Kitabevi Yayınları

Orhan, G. (2013). “Türkiyede Çevre Politikaları: Değişen Söylemler, Değişmeyen Öncelikler”, MEMLEKET Siyaset Yönetim, 19-20

Orhan, G. (2013). “Yerel Yönetimler ve Küresel İklim Değişikliği”, Yakup Bulut (ed) Kuramdan Uygulamaya Yerel Yönetimler ve Kentsel Politikalar, Ankara Pegem Akademi, 2013, 601-616 (https://www. researchgate.net/publication/323557525)

Pierson, P. (2000). "Increasing Returns, Path Dependence, and the Study of Politics", The American Political Science Review, Vol. 94, No. 2 (Jun., 2000). pp. 251-267

Saatçi, M., Dumrul, Y. (2011). Çevre Kirliliği ve Ekonomik Büyüme İlişkisi: Çevresel Kuznets Eğrisinin Türk Ekonomisi İçin Yapısal Kırılmalı Eş-Bütünleşme Yöntemiyle Tahmini, Erciyes Üniversitesi İktisadi ve İdari Bilimler Fakültesi Dergisi, 37/1, 65-86.

SETA (2017). “Türkiye’nin Milli Enerji ve Maden Politikası”, SETA Analiz Raporu, Siyaset, Ekonomi ve Toplum Araştırmaları Vakfı, İstanbul

Şahin, Ü. (2016). "Warming A Frozen Policy: Challenges To Turkey’s Climate Politics After Paris”, Turkish Policy Quarterly, volume:15, 2: 117-129

Şahin, Ü. (2014). Türkiye’nin İklim Politikalarında Aktör Haritası, İstanbul Politikalar Merkezi

Toprak, Z. (2012). Çevre Yönetimi ve Politikası, İzmir: Albi Yayınları.

Türk, B., Erciş, A. (2017). “Türkiye'de Çevre Politikası ve Uluslararası Çevre Sözleşmeleri”, The Journal of Academic Social Science Studies, 54: 351-392. doi: 10.9761/JASSS6929

Yıldırım, U., Budak, S. (2010). “AB Tam Üyelik Sürecinde Türkiye’nin Çevre Politikasındaki Değişimler”, Mustafa Kemal Üniversitesi Sosyal Bilimler Enstitüsü Dergisi, 13: 173-191

Yıldı, M. ve Sobacı, M. Z. (2013). Kamu Politikası Kuram ve Uygulama, Adres Yayınları

\section{Resmi Belge ve Diğer Dokümanlar}

Türkiye Cumhuriyeti İklim Değişikliği Eylem Planı 2011-2023, T.C Çevre ve Şehircilik Bakanlığı 
Türkiye’nin İklim Değişikliği Uyum Stratejisi ve Eylem Planı 2011-2023, T.C Çevre ve Şehircilik Bakanlığı Türkiye İklim Değişikliği Uyum Stratejisi 2010-2023, T.C Çevre ve Şehircilik Bakanlığı

Türkiye Ulusal Yenilenebilir Enerji Eylem Planı (2014). T.C Enerji ve Tabii Kaynaklar Bakanlığı

Kadıköy Belediyesi İklim Adaptasyon Eylem Planı, Kadıköy Belediyesi

Kadıköy Belediyesi Sürdürülebilir Enerji ve İklim Adaptasyon Eylem Planı, Kadıköy Belediyesi 2018

Bütünleşik Kentsel Gelişme Stratejisi Ve Eylem Planı 2010-2023, Ankara

TBMM’nin İklim Değişikliği Politikasındaki Rolü (http://onderalgedik.com/yedek/wp-content/ uploads/2016/02/TBMM-ve-I\%CC\%87klimDegisikligi-Raporu.pdf). 2016, Ankara

\section{Mülakatlar}

-Doç. Dr. Semra Cerit Mazlum, Marmara Üniversitesi (26.02.2019)

-Dr. Ümit Şahin, İstanbul Politikalar Merkezi-Sabancı Üniversitesi (19.03.2019)

-Ali Tulumen, Kadıköy Belediyesi-Çevre Koruma ve Kontrol Müdürlüğü (15.04.2019) 


\title{
Climate Change Policy in Turkey: A Perspective of Analysis through Historical Development, International Negotiations and Administrative Obstacles
}

\author{
Fethi Ufuk ÖZIŞIK
}

The agenda-setting of climate change policy in Turkey goes back to the acceptance process of the Kyoto Protocol. From this process, central administration begins to develop certain policies and measures at the same time to make institutional structures. By referring to various factors and issues, this work aims to examine the characteristics and limits of climate change policy in Turkey, according to the objective of reducing emissions of greenhouse gases. On a theoretical level, this work chooses to adopt an approach in terms of the analysis of public policies. In this sense, the interest is to first put in place a historical perspective by emphasizing the origins of climate change policy, that is to say, the general characteristics of environmental policies. Then, attention is paid to the different phases of public action in this area (Muller, 2006). From the process of setting the agenda to that of implementation, the work is also interested in contextualization of this public policy. The international context, the context of other public policies such as energy policies, the political context and the institutional context are taken into account to deepen the analysis (Hassenteufel, 2008). In this perspective, this work questions the main characteristics of the climate change policy in Turkey. What are the main motivations of the government in this matter? What factors determine and shape this policy? What are the limits? What is the administrative and institutional capacity in the implementation? Or how can we describe the articulation of the different levels of administration in this process? Of course, the particularity of this work also lies in its consideration of the local level of public action. In many countries, the climate change policy is also reflected in the initiatives undertaken by local governments and regions (Mazlum, 2009 and Orhan, 2014). To what extent does the country's tradition of centralized administration allow local actors to act in this area? Methodologically, we have chosen to study the academic work published in Turkey in order to be able to position ourselves in the literature. In this step, we noted the absence of a publication in Turkey, drawing inspiration from the analysis of public policies. So, we adopted an approach with the concern of articulating the

* Marmara University, Department of Political Science and Public Administration, ufuk.ozisik@marmara.edu.tr 
question of climate change with different contexts and with different public policies. Of course, we have tried to show also the administrative structures and strategies and action plans without forgetting certain statistics and certain quantitative data. The consideration of the local level was one of the focal points of analysis of this work. In this perspective, we chose to carry out fieldwork by interviewing local interlocutors, so we had an interview with an expert of the municipality of Kadıköy in Istanbul. Finally, we also chose to conduct interviews with two academics who publish on the subject but also who participate in the political process as experts. These interviews, beyond their existing publications, helped us a lot to understand the question as a whole. Indeed, from these questions and methodological approaches, it is possible to make certain observations. First, we have observed that in Turkey, climate change is not yet a priority on the political agenda. Even if it is possible to identify the emergence of certain initiatives concerned with the environment, the government seems far from putting in place an integrated strategy in this area. The lack of coordination in different public policies that interact to reduce emissions shows this. On the institutional level, this weakness of coordination and determination remains despite the establishment of certain administrative structures in a top-down logic and without really engaging non-state actors such as associations, experts or academics. Another remark appears in the general conception of the government with regard to climate change. The government in Turkey still considers the subject as a subject of foreign policy based on its disagreements with the international climate regime (Mazlum, 2017). Turkey relying on the narrative of "special circumstances" adopted a reticent approach vis-à-vis the sine qua non objective of international negotiations: to reduce emissions of greenhouse gases. The non-adoption of the Paris Agreement continues and reinforces this positioning. The discourse of "special circumstances" constitutes the basis of this approach by referring to the "unfair" status of Turkey in the climate regime, a status which places it in the rank of the developed countries by obliging it to achieve direct reductions and by making it devoid of funding mechanisms accorded to developing countries (Mazlum, 2017 and Şahin, 2016). In this logic, the priorities in the fields of energy, finance, and economic growth policies effectively prevent the development and implementation of an integrated and coordinated policy to reduce greenhouse gas emissions in Turkey. Finally, it is possible to admit that local governments seem far from being able to contribute to the fight against climate change. On the one hand, the initiatives remain singular without obligations and objectives set by the central government. Thus, Turkey does not have a standardized strategy at the local level. On the other hand, the central administration does not financially support these local initiatives. On the contrary, the increasing administrative centralization of recent years seems to prevent local administrations in their initiatives by imposing the rule and domination of the central administration on local governors and therefore, moving further and further from the policies of decentralization started in the early 2000s. 